\title{
anu \\ COVID-19 Influence on Developments in the Global Beef and Sheep Sectors
}

\author{
Mohamad Isam Almadani ${ }^{1, *\left(\mathbb{D}, \text { Peter Weeks }^{2} \text { and Claus Deblitz }\right.}{ }^{1}$ \\ 1 Thünen Institute of Farm Economics, Bundesallee 63, 38116 Braunschweig, Germany; \\ claus.deblitz@thuenen.de \\ 2 Weeks Consulting Services Pty Ltd., Sydney, NSW 2075, Australia; weeksconsultingservices@gmail.com \\ * Correspondence: mohamad.almadani@thuenen.de; Tel.: +49-531-596-5159
}

Citation: Almadani, M.I.; Weeks, P.; Deblitz, C. COVID-19 Influence on Developments in the Global Beef and Sheep Sectors. Ruminants 2022, 2, 27-53. https://doi.org/10.3390/ ruminants 2010002

Academic Editor: Brian J. Leury

Received: 18 October 2021

Accepted: 20 December 2021

Published: 23 December 2021

Publisher's Note: MDPI stays neutral with regard to jurisdictional claims in published maps and institutional affiliations.

Copyright: () 2021 by the authors Licensee MDPI, Basel, Switzerland. This article is an open access article distributed under the terms and conditions of the Creative Commons Attribution (CC BY) license (https:// creativecommons.org/licenses/by/ $4.0 /)$.

\begin{abstract}
While the COVID-19 pandemic and associated government responses have had a substantial impact on consumers and meat supply chains worldwide, the effect on beef and sheep farming has been surprisingly small, short-lived and largely offset by other global influences. However, the impact has also varied greatly between countries and regions, largely due to differences in Government measures and in industry circumstances and influences. This study aims to provide insights into the pandemic's impacts throughout global beef and sheep supply chains, but with a focus on the farm level, particularly producer prices in 2020. At the centre of the study is an analysis of online questionnaire-based survey responses to the Global agri benchmark Beef and Sheep Network. The study also utilizes a variety of other studies and information sources to explore other potential factors that could have also driven beef and sheep sectors worldwide in 2020. It explores how these influences interacted with the effect of the pandemic. Food service sales were highly impacted by the pandemic, meat processing was temporarily disrupted in North America but global livestock prices remained high due, in large part, to the continuation of strong beef and sheep meat demand and imports in China.
\end{abstract}

Keywords: COVID-19; beef; sheep meat; supply chain; farm price developments

\section{Introduction}

As with many other sectors worldwide, global livestock supply chains have experienced significant disruption due to the emergence of the Severe Acute Respiratory Syndrome coronavirus 2 (SARS-CoV-2 or COVID-19) in early 2020 [1]. Since the priority is to protect the physical and psychological health of billions of people, governments rushed to impose rigorous sanitary measures to control the spread of the virus and those that could afford it launched huge fiscal stimulus and support programs. Measures taken worldwide have varied from drastic lockdowns, quarantines and border closures, to more relaxed measures to mitigate any socio-economic crisis sparked by the COVID-19 pandemic worldwide. According to the World Bank 2020 and the Organization for Economic Cooperation and Development (OECD), the pandemic has unleashed an unprecedented social and economic crisis, which may be long-lasting and break supply chains, limit access to essential services and raise food prices [2,3]. The mitigation measures have disrupted and altered value chains and local and global commerce [1,4]. Protecting the health of individuals has been the core concern but there has also been increased uncertainty around economic growth, trade and food security.

From the very beginning of the pandemic, many newspapers, reports and reviews have approached COVID-19's impacts on different agricultural production systems and supply chains. However, these contributions have principally aimed to highlight how the pandemic could threaten food sectors and supply chains in general rather than the threat to specific commodities or sectors. In this context, the OECD drew attention to potential damages that the pandemic and consequent control measures could cause to the global 
food and agriculture sector in the short-term [5]. Since then, researchers have provided observations on the potential negative impact of the pandemic on global agriculture, food supply chains and food security [6-10]. Some reports and reviews reported findings with regional and country-specific content [11-14].

Since late 2020, the impacts on specific agricultural sectors have begun to garner more attention. With respect to the livestock and meat sectors, the Global Agenda for Sustainable Livestock conducted a stakeholder consultation on COVID-19 in the livestock sector globally between April and May 2020 [4]. Reviews covering the livestock industry and meat production under the pandemic crisis have been conducted at global $[1,15,16]$ and regional levels [14,17-19]. Marchant-Forde and Boyle (2020) provided a deeper insight into the U.S. pig and poultry industries [20]. In January 2021, Animal Frontiers, the review magazine of North American and European animal science societies, tried to summarize how livestock, mainly pig and cattle, have been affected by the pandemic, providing examples from different countries and regions [21].

Apparently, a considerable amount of research has discussed, at some length, the pandemic's impact on agricultural activities in general but with less concentration on global beef and sheep meat production and supply chains. Some research efforts have been conducted on the beef sector in Canada [22,23] and the U.S. [24,25]. Evidence on sheep production has been reported in Spain regarding sheep milk and meat production [26] and the extensive sheep farming systems in Northeast Spain [27].

Research has emphasized the pandemic's impact on the livestock sector at the market level (supply, demand, consumer behaviour and trade) [24,28-31]. However, there is minimal evidence of how the pandemic has affected different beef and sheep production systems at the farm level, such as inputs availability, prices, production costs and returns. This indicates that further research is needed to quantify and assess COVID-19's impact on beef and sheep sectors in different countries.

The vast majority of livestock sector reviews and analyses have focused on the pandemic's impacts in isolation, while other factors and accompanying events impacting the sector, have been largely overlooked. Global beef and sheep meat sectors are becoming increasingly subject to a range of challenges arising from country-specific features, production systems' particularities, economic and natural conditions, market developments and trade agreements, and interactions between agricultural sectors [32,33]. These factors could either further compound or mitigate the pandemic's impacts, leading in turn to varying severity between countries and regions.

Therefore, this study goes beyond existing research to (i) investigate, in addition to COVID-19, a broader set of factors that may have impacted global beef and sheep sectors in 2020, represented by macro-economic conditions, market developments and natural conditions; (ii) provide a more complete coverage for beef and sheep production and supply chains with a particular focus on the farm level.

The study illustrates examples and evidence obtained from 32 beef and 21 sheep producer countries. This will be helpful to understand the factors and country- and production system-specific characteristics that have led to different impacts and implications of this unprecedented pandemic. Such a comprehensive understanding could be helpful for beef and sheep producers and agribusiness to formulate future management interventions for more stable beef and sheep production and value chains.

\section{Materials and Methods}

\subsection{Research Framework}

The pandemic unprecedentedly challenged beef and sheep meat supply chains, impacting producers, processors, marketers and consumers $[5,8,11,34]$. It is to be expected that beef and sheep farming systems would have been directly and indirectly impacted by this supply chain disruption, potentially affecting beef and sheep supply, farm productivity and producer prices. Figure 1 provides an overview of the potential impacts at the farm 
level, caused directly by the pandemic or indirectly by the disruptions at meat plants and markets that were investigated within this study.

The direct impacts could be represented by disruptions in farm input flows and product marketing, which could highly impact beef and sheep supply, farm productivity and producer prices [1].

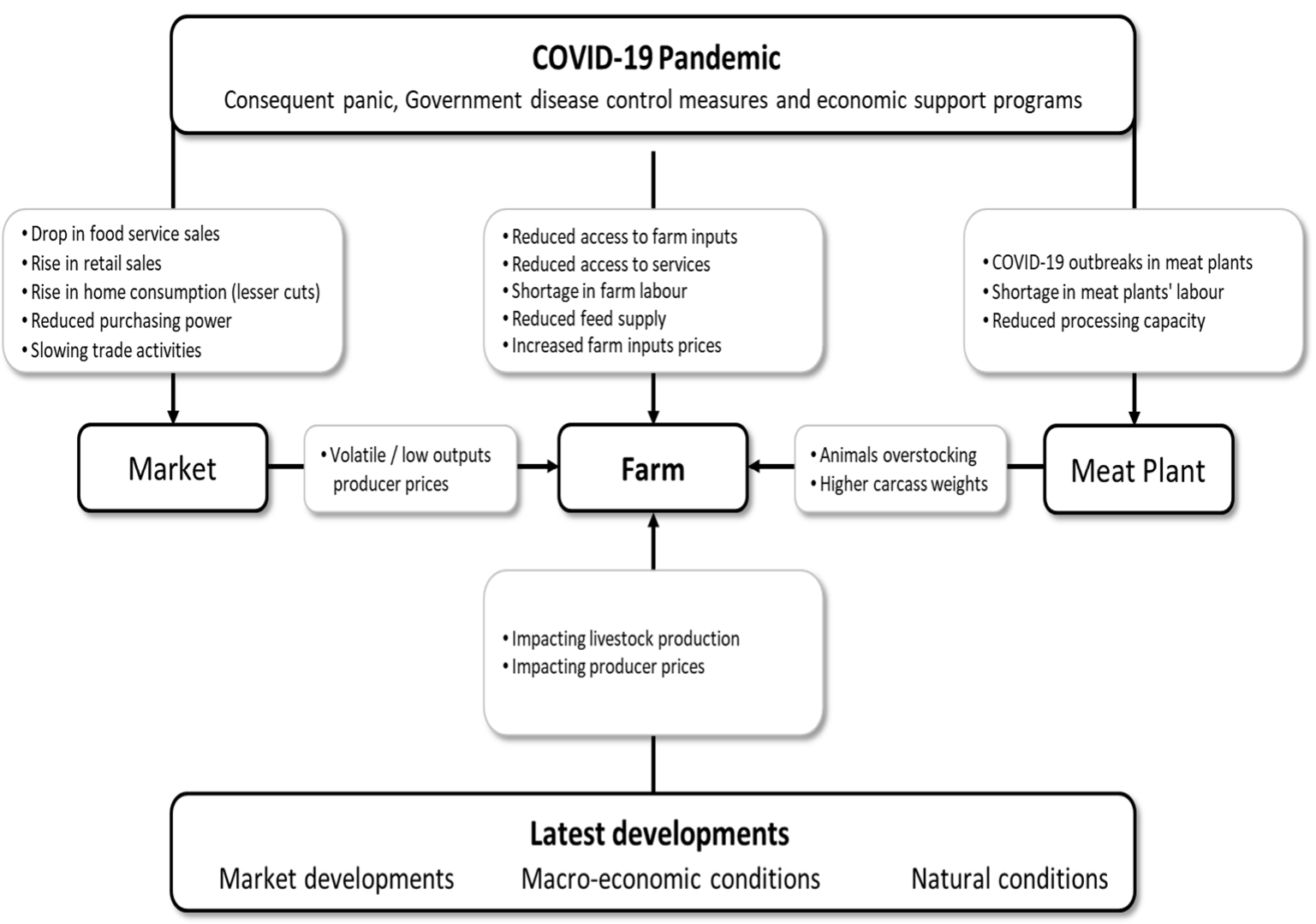

Figure 1. Scheme of investigated impacts of COVID-19 and the latest developments worldwide on global beef and sheep farming systems.

At the processing and packing level, movement restrictions, social distancing and the high potential of virus outbreaks in these labour-intensive sectors contributed towards a decrease in the slaughtering and processing capacity of meat plants $[1,16]$.

This study investigates the pandemic's impact on local consumption and the global marketing of beef and sheep meat, as the sudden restriction of social and economic activities are expected to have limited consumer purchasing power, market capacity and export and import operations. Due to the major socioeconomic consequences of the pandemic, its impacts continue to affect food demand and consumption, having reduced consumers income and lowered purchasing power in some countries $[5,8,11]$.

Beef and sheep production at the farm level can be indirectly impacted by interruptions at processing and marketing levels. With the closure of processing plants, together with market disruptions, beef and sheep farmers are expected to have experienced a backlog of market-ready cattle and potential overstocking [1].

In low-income countries, where the bulk of livestock farming occurs in traditional small-scale systems, reduced market opportunities threaten farmers' livelihoods. These are mainly subsistence-oriented producers and they need cash flow for feeding their families and animals $[1,11,16,18]$. In this context, the FAO guidelines to mitigate the impact of the COVID-19 pandemic on livestock production and animal health [35] listed many programs and projects that have been postponed or suspended at the national and international levels due to the pandemic. 
As this study aims to go beyond the pandemic's impacts, it explores other potential factors that could have also driven beef and sheep sectors worldwide in 2020. Almadani et al. (2021) introduced a comprehensive overview of factors that have influenced global beef and sheep meat production and prices over the last two decades. The research framework addresses these factors under the "latest development issues" as follows: (i) macro-economic conditions (exchange rate developments, political instability, inflation and economic recession); (ii) market developments (changes in supply, demand and trade regulations) and natural conditions (climate conditions and animal disease) (Figure 1).

\subsection{Data Sources and Analysis}

Multiple data sources have been harnessed to fulfil the study objectives (Table 1). Based on an in-depth analysis of previous studies and observations, an online questionnaire-based survey was developed, comprising two sections; potential impacts of the pandemic and relevance of latest development issues. A five-point Likert scale $(1=$ not at all to $5=$ severe impact) was identified to quantify the pandemic's impact on a set of statements presenting potential impacts of the pandemic at the farm, meat plant and market levels throughout 2020. The latest development issues have been addressed in the questionnaire as closed questions (relevant/not relevant), with an open area to describe the relevant issues in more detail. The questionnaire can be found in Figure A1 (in Appendix A).

Table 1. Overview of multiple data sources adopted in the study.

\begin{tabular}{|c|c|c|c|}
\hline \multicolumn{3}{|c|}{ Data Source } & \multirow{2}{*}{$\begin{array}{c}\text { Purpose } \\
\text { Quantify the pandemic impact }\end{array}$} \\
\hline & Online questionnaire-based survey to & Five-point Likert scale & \\
\hline & $\begin{array}{l}\text { the agri benchmark Beef and Sheep } \\
\text { Network partners (April-May, 2021) }\end{array}$ & $\begin{array}{l}\text { Closed questions } \\
\text { (relevant/not relevant) }\end{array}$ & $\begin{array}{l}\text { Explore the relevance of the latest } \\
\text { development issues }\end{array}$ \\
\hline \multicolumn{3}{|c|}{$\begin{array}{l}\text { - Online poll to the agri benchmark Beef and Sheep Network partners during the } \\
\text { network Conference (June 2021) using the polling panel of Webex Meetings App., } \\
\text { Cisco Systems, Inc. }\end{array}$} & $\begin{array}{l}\text { Observe any improvements regarding } \\
\text { beef and sheep meat supply chains } \\
\text { and producer prices during the } 1 \text { st } \\
\text { half, } 2021\end{array}$ \\
\hline \multicolumn{3}{|c|}{$\begin{array}{l}\text { - } \quad \text { agri benchmark database } \\
\text { - } \quad \text { Personal communication with the agri benchmark Beef and Sheep Network partners } \\
\text { - } \quad \text { Official data sources (national and international organizations) } \\
\text { Third-party materials (published reports, peer reviewed and news articles) }\end{array}$} & $\begin{array}{l}\text { Drive deeper insights into the } \\
\text { developments of beef and sheep } \\
\text { sectors in } 2020 \text { across the globe }\end{array}$ \\
\hline
\end{tabular}

The online survey was circulated to all the agri benchmark Beef and Sheep Network Partners in April 2021. The agri benchmark network is a global non-profit network of agricultural economists, experts and livestock producers from 50 institutional partners, covering most of the relevant producing countries and the global variety of production systems [36,37]. Beef production systems are represented by 33 countries with almost all the major producing countries included except India, representing approximately 76\% of global beef production in 2019. The network covers sheep production systems from 21 countries, which represented 59\% of global sheep meat production in 2019. Beef and sheep meat production in the agri benchmark network countries is shown in Figure A2, in Appendix A. The agri benchmark Network Partners, who are members of the agri benchmark partners' institutions, were asked to answer the survey for their countries using relevant statistics, research, reports, newsletters and other materials available at the national level. Thus, the results are based on a mix of available data and statistics on the one hand and expert assessments on the other.

Responses were analysed and results presented during a workshop presentation conducted on 15 June as a part the 19th annual agri benchmark Beef and Sheep Conference, 2021 (online). During the workshop presentation, partners were asked, via a poll, if they had observed any improvements regarding beef and sheep meat supply chains and prices during the first half of 2021. The poll statements are shown in Figure A3, in Appendix A. 
As this study aimed to comprehensively capture insights into the developments of global beef and sheep sectors in 2020, it gathered further evidence using external data sources (Table 1).

The agri benchmark Beef and Sheep Network Database encompasses a comprehensive set of sector and farm data on beef cattle and sheep farming systems in the network countries which are provided and updated by the network partners on an annual basis from national statistics $[33,36]$. The study adopted the agri benchmark database to monitor changes in a set of sector and farm indicators in the network countries in 2020 . The sector-related indicators cover national beef and sheep meat production, consumption, exports and imports, while farm level indicators reflect farm input prices and output producer prices.

\section{Results and Discussion}

This section points out, based on the online survey results, the partners' evaluation of the pandemic's impacts on the global beef and sheep sectors and the latest development issues in the sectors. Thereafter, the results will be discussed by providing further supporting evidence driven by multi data sources introduced in Table 1 . Poll results on the sector developments during the first half of 2021 will be presented at the end of this section.

\subsection{COVID-19 and Global Beef and Sheep Meat Markets \\ 3.1.1. Survey Results on Meat Markets}

Figure 2 provides an overview of the perceived severity of COVID-19's impact on different marketing activities. As anticipated, all partners reported some impact on awayfrom-home consumption, including food service activities, and a quarter reported a severe impact. Large-scale social restrictions have slowed down the global tourism sector, mainly hotels and restaurants. Moreover, food service and out-of-home facilities, such as canteens, buffets, quick service restaurants, fast food outlets and barbecues, were adversely impacted worldwide.

The first wave of impacts, when restaurants and food service outlets were totally closed, caused an initial surplus of beef and sheep meat in some countries-in particular, premium cuts. However, panic buying of food followed the first shock, as consumers stockpiled food at home, exacerbating the surge in retail trade [21]. These sudden market shifts were hard to cope with in many western economies, where food service and retail meat supply chains are highly specialized, and distribution systems are largely separate. For example, meat products provided to food service channels are not subject to the same packaging and labelling requirements as ready retail sales. This caused bottlenecks in the meat supply chains during the first three months of the pandemic [34,38].

Despite the impacts of the pandemic on household incomes and on eating out in 2020, domestic beef and sheep meat demand and consumption was less impacted over the network countries. Over $40 \%$ of respondents reported that the pandemic did not cause any reduction in domestic beef and sheep meat demand and consumption overall in 2020, whereas $28 \%$ indicated only a minor reduction $-26 \%$ indicated a moderate or significant reduction in consumption and none reported a severe reduction.

The pandemic's impact on the food service demand for beef and sheep meat and on supply chains was expected to have some negative impact on international trade demand and to shift trade flows. This was the case, but the impact was less than expected, with $28 \%$ of survey respondents reporting at least a moderate slowing of trade and $56 \%$ a minor negative impact. Similarly, the vast majority reported some shift in trade flows, with $25 \%$ reporting at least a moderate shift in trade flows and $56 \%$ only minor shifts. 
Drop in out-of-home consumption

Drop in food service sales

Economic hardships, reduced household incomes

Slowing trade activities

Large shifts in export/import destinations

Reduced domestic demand and consumption

Increased consumers' concerns about meat origin

Overcrowded cold storage facilities

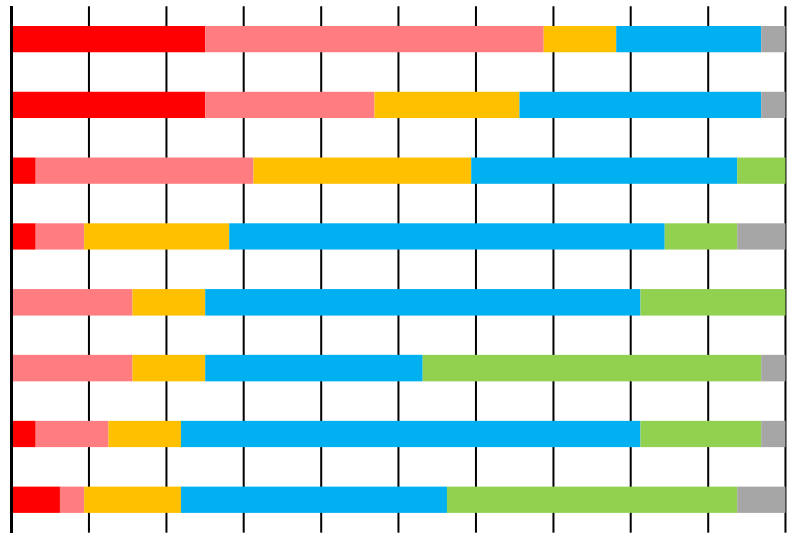

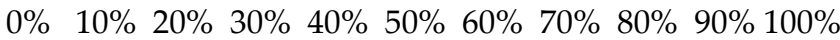

Severe $\square$ Significant $\square$ Moderate $\square$ Minor $\square$ Not at all $\square$ Don't know

Figure 2. COVID-19 impacts at consumer market level in 2020; Data source: Online survey data (n: 32).

\subsubsection{Discussion on Domestic Meat Demand and Consumption}

Since it first appeared in China in December 2019, the virus has spread across the globe, but it emerged and surged at different times across regions and countries. The first wave in Europe and North America commenced in March 2020 and first peaked in winter (December 2020/January 2021), while the first peak in South America and India was be-tween August and October 2020, followed by a much larger peak in mid-2021 [39].

The timing and extent of the pandemic's impact on beef and sheep meat consumption also varied greatly across countries and even regions within countries due to the vast differences in Government disease control measures, especially lock-downs and border controls. While recognizing these differences in the timing and extent of the COVID-19 disease outbreaks and Government responses, there are striking similarities in the overall impacts of the pandemic on consumers and consumption across the world.

With prolonged lockdowns, "stay at home" orders and many citizens working from home, a huge shift in beef and sheep meat consumption occurred from away-from-home to at-home consumption. This resulted in increased household demand for beef and sheep meat, particularly mince $[21,40]$. Retail outlets, online and e-commerce food delivery platforms and creative solutions at food service facilities (such as drive thru, takeout, curbside, home delivery and take-away options) have adequately compensated for the lower demand in traditional food service chains in the majority of the network countries $[15,34,38]$.

Livestock and Meat Domestic Data of USDA estimates that per capita consumption of beef in the U.S. was maintained in 2020 at the 2019 level of $26.5 \mathrm{~kg}$ [41]. Similarly, a slight increase in total beef consumption in 2020 (3\%) was recorded in Canada [42]. In the UK, the drop in food service sales for beef was compensated through increased retail sales, even of high priced cuts, causing a slightly higher beef consumption overall, by $3 \%[42,43]$.

Food service sales in China were temporally impacted in the first quarter of 2020 but recovered quickly after that. The shift from wet meat markets was accelerated by the pandemic's impact, with more consumers turning away from traditional retail and using more online retail [44]. While a low 3\% of fresh food consumed in China pre-pandemic was sold through online food delivery platforms, this increased fourfold by February 2020 [45]. Consequently, a significant increase (9\%) in beef consumption was reported in 2020 [42]. Despite $65 \%$ of the national sheep meat consumption in China being away-from-home [33], national consumption was not impacted by the COVID-19 lockdowns. High-end restaurants in larger cities, as the most popular venues for dining out on lamb, were able to meet the demand during lockdowns through online retail. Moreover, the widespread grilling of low value cuts of sheep meat in northern China was able to continue in summer 2020. 
Given the "dining-out" tradition in Spain and consumer preferences for social meals over individual meals, social distancing orders and diminished tourism sharply impacted the demand for beef and lamb [26]. However, higher consumption within households and efforts by operators in beef and sheep sectors, along with promotion initiatives, allowed national consumption to increase. The strong beef retail demand in Spain pushed up domestic consumption in 2020 by $9 \%$ compared to 2019 , mainly for cheaper cuts such as minced meat. Similarly, per capita consumption of sheep meat in Spain increased for the first time since 2007 to reach $1.6 \mathrm{~kg}$ / capita in 2020, up from $1 \mathrm{~kg}$ /capita in 2019 [42].

In addition to North America, most of the EU partners indicated an increase in beef and sheep meat consumption in their countries in 2020. This can be attributed to national fiscal spending programs in some countries, helping consumer demand for beef and sheep meat to bounce back quickly, and even to increase. According to the International Monetary Fund (IMF) 2021 [46], there was a big fiscal stimulus by some developed country governments, especially the U.S., the UK, Australia and Canada (Figure 3). In contrast, low spending has been observed in many developing countries such as Mexico, Argentina and South Africa.

Comparing the fiscal spend with the extent of the fall in economic growth across the selected countries showed the expected inverse relationship, but it is not as clear or uniform as might be expected-indicating that particular economic or consumer characteristics or economic drivers were also having a large influence on economic growth in many countries in 2020. Thus, countries such as France and Spain had big stimulus spending yet still incurred large, above average falls in GDP growth in 2020. Similarly, China witnessed relatively small falls in GDP despite having only small COVID-19 related fiscal spending.

The EU countries have reallocated public funding to support crisis priorities. Similarly, measures supporting subnational finance and relaxing fiscal rules have been applied by two thirds of OECD countries [3].

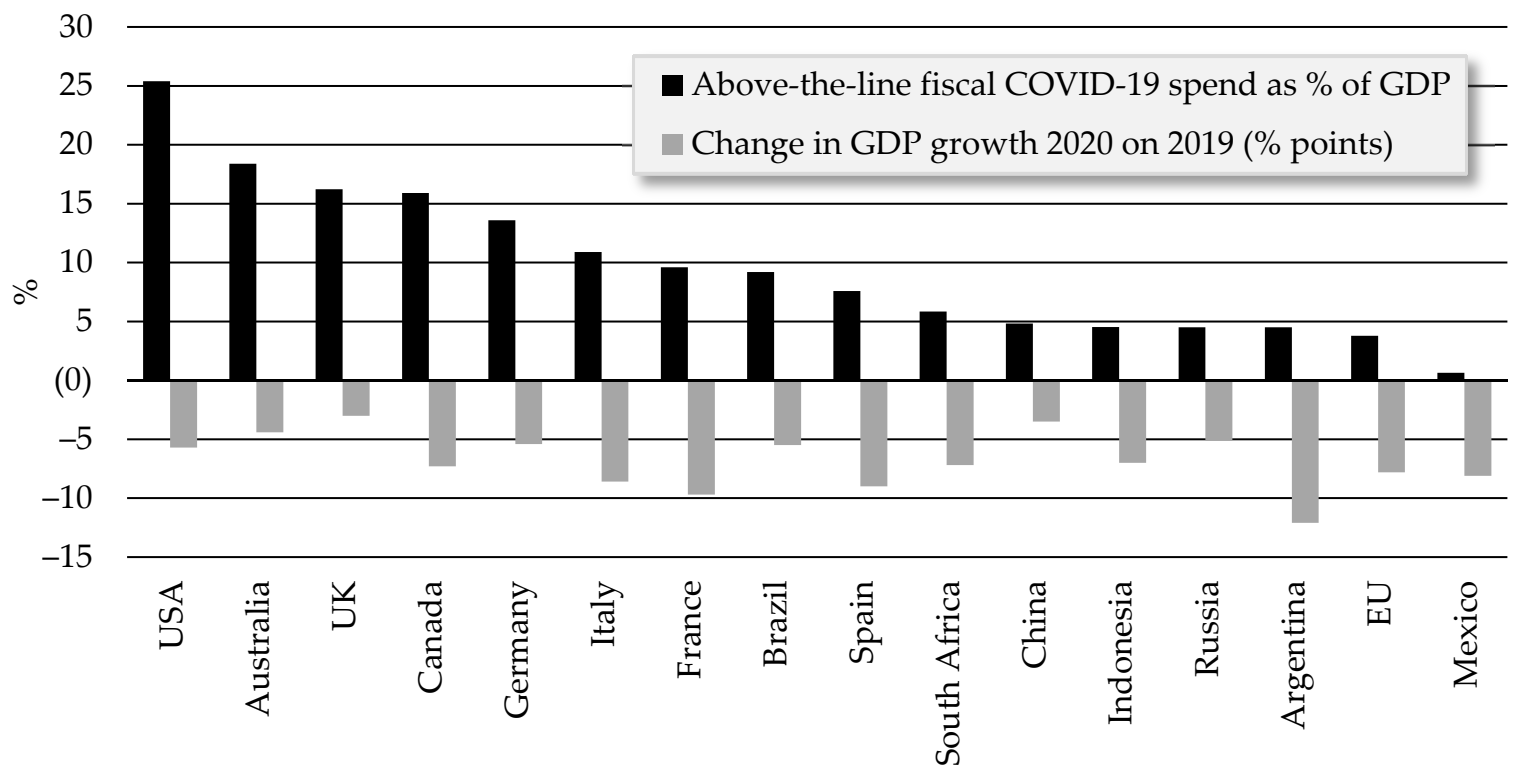

Figure 3. COVID-19 related above-the-line fiscal spending and GDP growth between 2019 and 2020 in selected countries, Data source: IMF Database [46]. (Above-the-line fiscal spending including money spent since January 2020 or announced as of 5 June 2021, for implementation in 2020, 2021 and beyond, as a percentage of annual GDP. GDP growth in 2020 is the percentage point change in GDP growth between 2019 and 2020, not as percentage change in absolute GDP in 2020).

All African and South American countries in the network reported that the pandemic caused economic hardships and a significant reduction in household purchasing power. This was a critical factor eroding demand for beef and sheep meat in some countries at the expense of lower priced meat, such as pork and poultry. Brazil and Argentina have been 
experiencing low economic growth and recessions for a decade. This has severely affected consumer demand for beef [33]. COVID-19 and related economic hardships have further compounded the fall in consumer purchasing power. Beef retail prices in Argentina, as of June 2020, increased by $53 \%$ year-on-year, which is above the inflation rate of $42.8 \%$. Higher retail prices, together with low incomes and job losses due to the pandemic, made beef less affordable [47]. Statistics showed that beef consumption in Argentina declined by $3 \%$ in 2020 to reach an all-time low of $50.22 \mathrm{~kg} /$ capita [48]. While Argentinians prefer beef over other meats, they became more inclined to buy lower-priced proteins, mainly pork. Per capita consumption of pork in Argentina increased by 11\% in 2020 compared to 2019 [49].

Similarly, economic hardships and a reduction in consumer purchasing power in Brazil caused by the pandemic reduced per capita consumption of beef by $8 \%$ in 2020 , while the demand for chicken, the cheapest meat, increased by $7 \%$ [42,50,51].

Lower sheep meat consumption has also been observed in Algeria, Namibia and Tunisia as the purchasing ability of low and middle-class families has fallen [42].

\subsubsection{Discussion on International Trade}

Global meat trade was observed to be impacted by two main issues: interruptions at meat processing plants and slowing food service sales. However, the level and direction of these impacts were very diverse between countries. Figure 4 shows beef exports to the top five destinations from Brazil and the U.S. between 2018 and 2020, being two of the world's largest beef exporters and having contrasting COVID-19 impacts. While U.S. beef exports in 2020 declined by $4.9 \%$, Brazil lifted volumes of beef exported by $8 \%$.

Bottlenecks in the U.S. beef supply chain and food service closures waves in key import markets for U.S. beef in North Asia led to significant supply disruptions to international trade. U.S. beef exports plummeted by $30 \%$ in May 2020 compared to pre-crisis levels in March. In contrast, Brazil's exports of beef grew by about 19\% during the same period [30]. This can be attributed to the weak domestic economy and spending, and strong export demand from China, which made exporting much more attractive. There was massive demand growth from China-Brazil's exports to China increased by $75 \%$ in 2020 . While U.S. beef exports to China increased by $25 \%$ in 2020, the export share to Japan and South Korea, as the top two destinations for U.S. beef, declined. Food service has continued to face COVID-19 related challenges, prolonging the impact on exports of high value beef cuts to Asia [52].

The prolonged lockdowns of food service activities hindered the internal beef and sheep meat trade between EU countries, as the bulk of this trade is targeted at food service outlet in these countries. Beef exports from Germany and the UK experienced a significant decline in 2020 - by $15 \%$ and $12 \%$, respectively [42]. France is a large lamb importer, sourcing half of its total sheep meat from the global market. In 2020, however, French imports of sheep meat fell $10 \%$ as the food service market, which is the main channel for imported lamb, in particular high value cuts, was thrown into turmoil by COVID-19 [42].

New Zealand, as the second largest sheep meat exporter, is another example highlighting the impact of slowing food service demand on the global lamb trade. EU, as a key importer of New Zealand lamb, showed a 5.5\% decline in volumes shipped in 2020 (Figure 5). As disease outbreaks in the EU shut down food service facilities in March, April and May, lamb imports from New Zealand plummeted by 52\%, from 11.2 million ton in March to 5.4 million ton in May. Demand in hotels and restaurants fell significantly in France and the Netherlands, pushing lamb imports down by $5 \%$ and $14 \%$, respectively. However, Germany maintained the 2019 import level from New Zealand. 


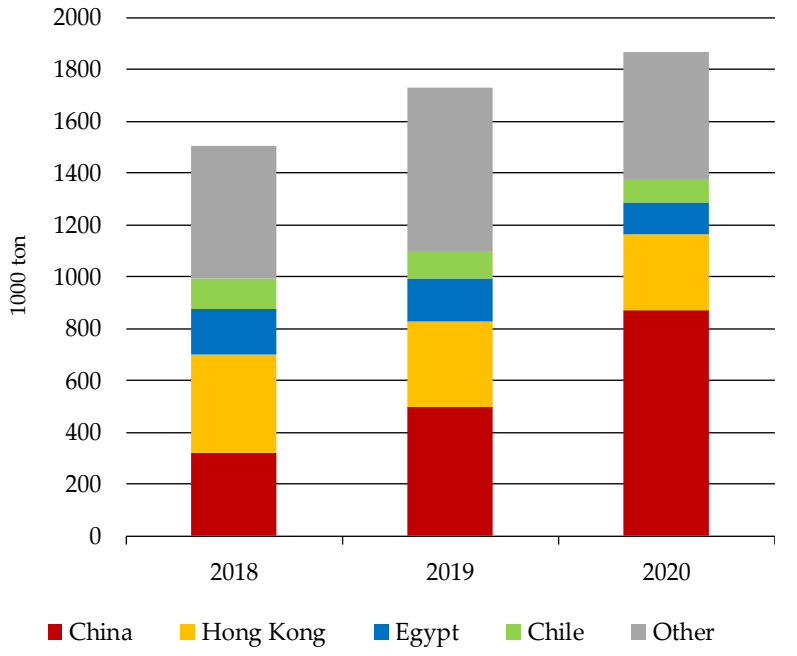

Brazil

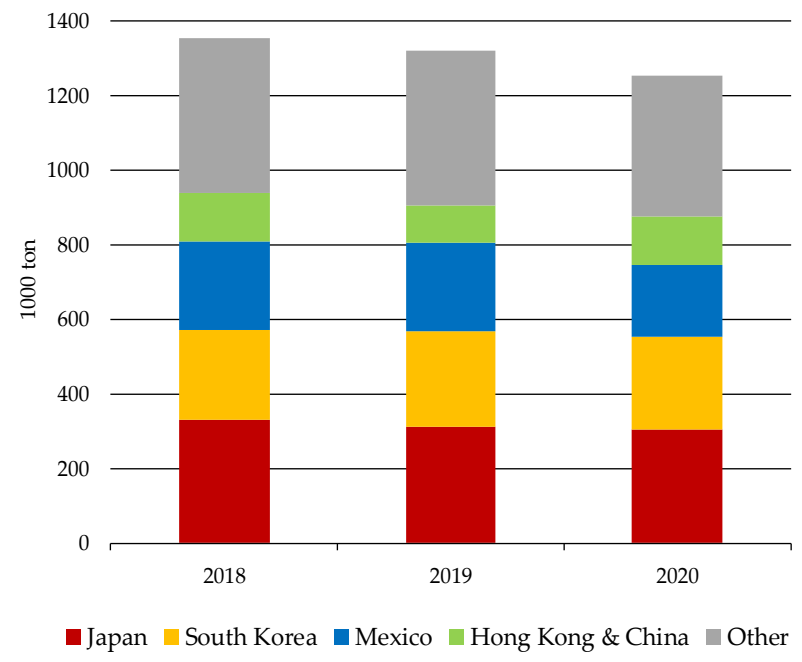

USA

Figure 4. Beef exports from Brazil and the U.S. to top five diestinations, 2018-2020, Data source: Brazil; Brazilian foreign trade statistics [53], USA; USMEF Export Statistics [54].

In contrast, New Zealand lamb exports to China remained stable in 2020 as the decline in food service sales was offset by sales through online food delivery platforms. As sheep meat is typically consumed in home cooked meals in Middle East countries, the region's imports of New Zealand lamb were not impacted by the pandemic in 2020, but grew by $10 \%$.
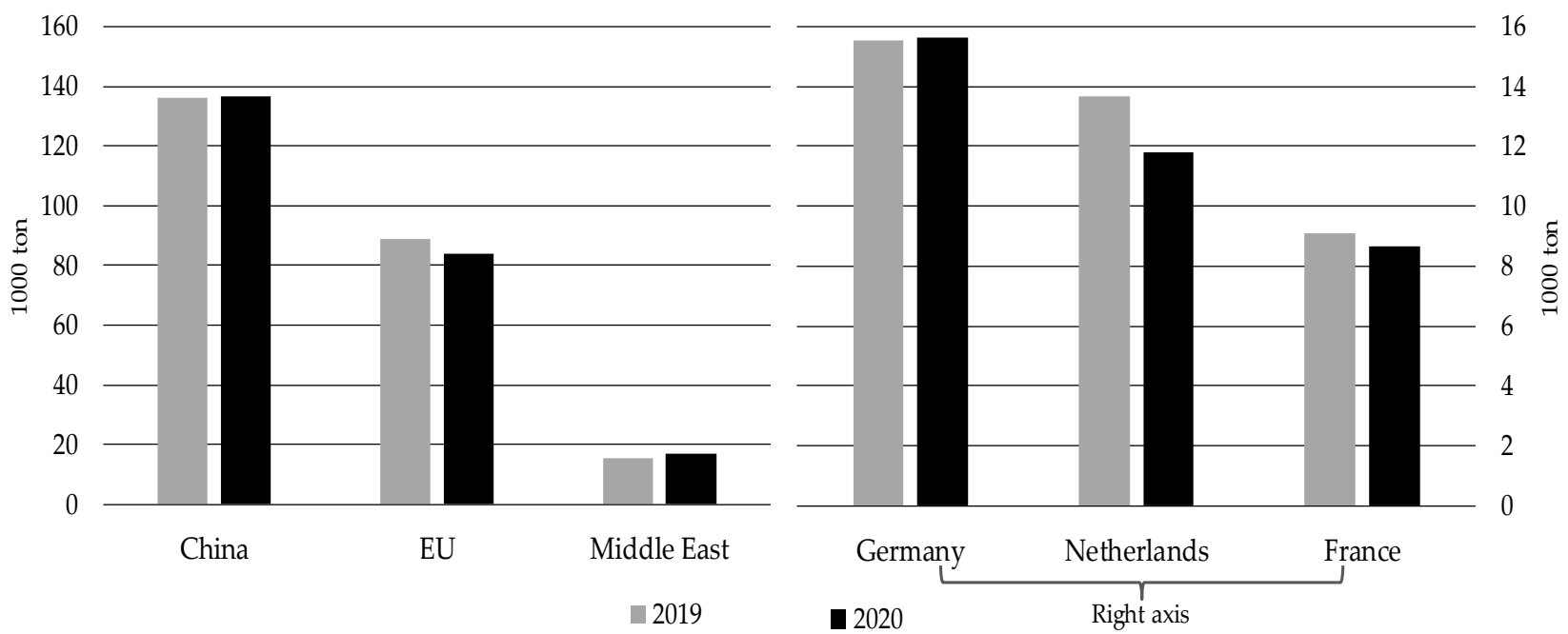

Figure 5. Lamb exports from New Zealand to the largest key import markets in 2019 and 2020, Data source: Meat Export Tool B + LNZ [55].

\subsection{COVID-19 and Global Beef and Sheep Meat Processing Plants}

3.2.1. Survey Results on Meat Processing Plants

Figure 6 shows how the network partners evaluated the pandemic's impacts on relevant meat plants' statements throughout 2020. While $80 \%$ of respondents reported COVID-19 outbreaks in meat plants, a shortage of labour and reduced capacity as issues for meat processing in their country, none reported a severe impact. The majority assessed all these impacts to be only minor- $25 \%-28 \%$ reported significant-to-moderate impacts on all three issues. 


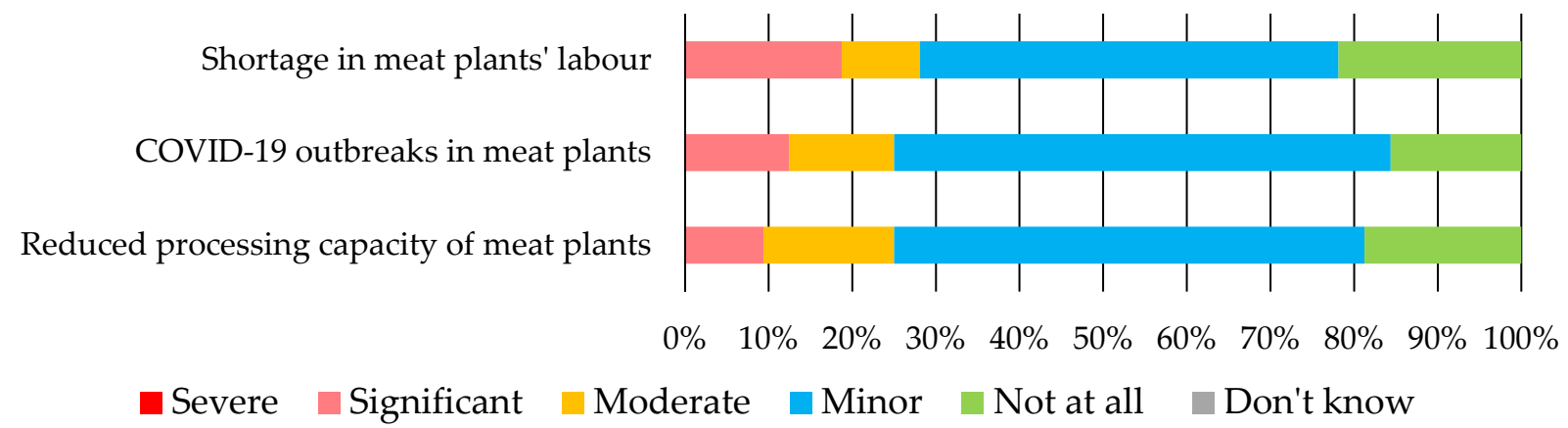

Figure 6. COVID-19 impacts on meat plants level in 2020, Source: Online survey data (n: 32).

\subsubsection{Discussion on Meat Processing Plants}

The results showed that the majority of network partners (56\%) indicated only a minor processing capacity reduction, and 19\% reported no impact at all. Among key beef producers in the network, North American countries responded that COVID-19 has led to a significant reduction in meat packing plants in 2020, whereas South American partners rated this reduction as minor. This variance can be attributed to the variation in national quarantine measures and the extent of meat plants' commitment to these measures. Agricultural activities in Argentina were exempted from restrictions imposed by the government on operations and movements [47]. Therefore, the Argentine meat processing sector had more flexibility to manage their business under the pandemic. In Brazil, some infected plants continued to operate by suspending only those who tested positive from work instead of ordering a full closure [56].

At the beginning of the epidemic's spread, the literature showed that meat plants, where employees work closely together along the processing lines, were major threats for spreading the COVID-19 infection. Accordingly, they were forced to temporarily close to prevent the virus breaking out on a larger scale. Between May and July 2020, several largesized meat packing plants in North America and Europe witnessed temporary closures as many workers tested positive [8,22,57-60].

Restrictions on free movement across borders and suspensions of the visas for foreign workers have significantly impacted meat processing from the 2nd quarter of 2020. This issue was one of the primary concerns in North America and Western Europe [61].

In Germany, there were reports that migrant workers living together in poor housing conditions had inadequate hygiene measures, causing COVID-19 outbreaks in several meat processing plants across Germany between May and July 2020 [62,63]. Therefore, in November 2020, a law banning subcontracting in the meat sector was officially agreed upon by the German government, and entered into force on 1 January 2021 [64,65]. Slaughterhouses and processing plants had to deal with these abnormal situations and reduce processing capacity.

Disruptions at slaughterhouses and processing plants adversely impacted processing capacity in North America and Europe during the first three months of the pandemic. In May 2020, fed cattle slaughter across the U.S. declined by $41 \%$ year-on-year [57]. The cattle slaughter rate in Canada was down sharply in April and May 2020 by $27.5 \%$ and 31.1\% year-on-year, respectively [22]. Vidaurreta et al. 2020 reported a drop in lamb slaughter in Spain by 25.9\% in April 2020 compared to April 2019 [26].

Based on the foregoing, we conclude that the disruption at slaughterhouses and meat packing plants in the network countries appears to have been a short-term issue, limited to the first period of the pandemic. This is attributed to the rapid deployment of more advanced sanitary measures in meat plants, which played a significant role in controlling the spread of the virus and prevented any prolonged impact on meat processing [15]. 


\subsection{COVID-19 and Global Beef and Sheep Farming}

Partners' evaluations of the COVID-19 pandemic's impact on beef and sheep farming operations are presented in Figure 7.

High monthly volatility of finished animal prices

Delayed marketing of finished animals

Reduced producer prices (output prices)

Increased farm inputs prices

Shortage in farm labour

Reduced access to farm inputs

Reduced feed supply

Reduced access to services (e.g. veterinary extension)

Reduced pastoralists mobility

Reduced national livestock inventories

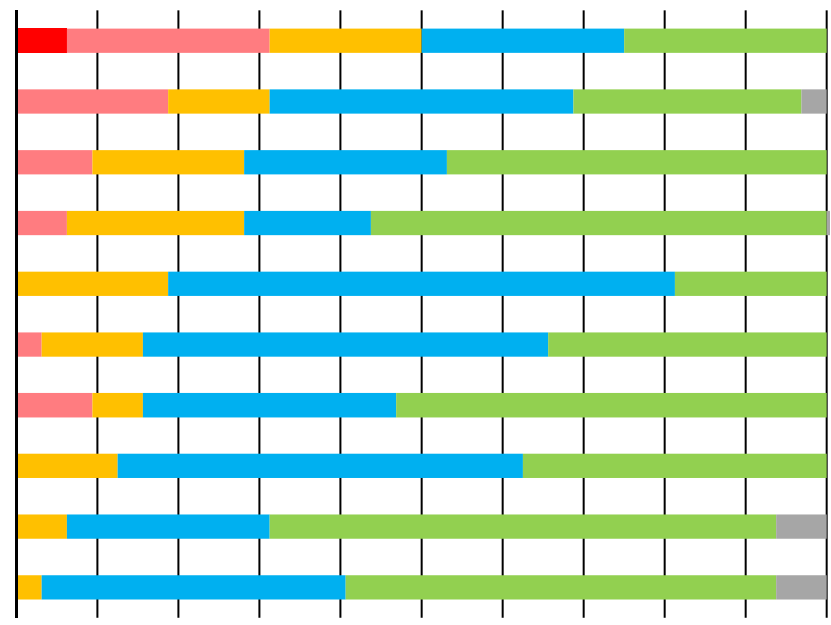

$\begin{array}{lllllllllll}0 \% & 10 \% & 20 \% & 30 \% & 40 \% & 50 \% & 60 \% & 70 \% & 80 \% & 90 \% & 100 \%\end{array}$

Severe Significant $\square$ Moderate $\square$ Minor $\square$ Not at all Don't know

Figure 7. COVID-19 impact on farm level in 2020; Data source: Online survey data (n: 32).

The pandemic has had some significant impacts on-farm in many countries, principally through the impact on output and input markets - falls in demand and prices for livestock outputs and reduced availability and higher prices for some inputs.

Statements addressing the impact on-farm product prices and marketing processes were ranked as the most affected. This applies to the delayed marketing of animals ready for slaughter, monthly volatility in finished animals' prices and declines in producer prices in 2020 (farm gate prices). These impacts are basically driven by the disruptions at slaughtering and marketing channels rather than the result of direct impacts on on-farm operations.

Partners from the U.S. and Canada indicated that COVID-19 had a severe impact on producer price volatility, while $25 \%$ and $19 \%$ of all respondents indicated a significant and moderate impact, respectively. This is mainly attributed to the gap between demand and supply resulting from bottlenecks in the supply chains at regional, national and international levels- $70 \%$ of network countries observed a delay in the marketing of finished animals in 2020.

In comparison to livestock marketing and prices, statements reflecting the direct impact of the pandemic on-farm input availability have been evaluated with less severity. The majority of respondents reported only minor impacts regarding the availability of farm inputs (feed, labour and services). Over $55 \%$ of the network countries did not observe any increase in the price of farm inputs arising from the COVID-19 crisis in 2020.

The research framework calls for a widening of this investigation of on-farm developments beyond the impacts stemming from the pandemic (centred on the on-line survey results above) to take account of other influences and assess how they interacted with the pandemic impacts. Hence, the on-farm discussion below draws on information from the partners' feedback on the latest development issues presented in the questionnaire.

\subsection{Latest Developemnt Issues Infleuencing Global Beef and Sheep Sectors}

\subsubsection{Survey Results on Latest Developments}

Figure 8 shows the most relevant latest development issues selected by each of the network partners as the key factors impacting beef and sheep faming systems in their countries in 2020. Partners in the EU countries, North America and China selected market 
related aspects, such as domestic demand and global trade flows, as having had the greatest influence on beef and sheep farming activities in 2020. Macro-economic conditions, represented by economic growth, inflation rate and exchange rate developments, were selected as the most relevant factors in South America, the Middle East and Eastern Europe. Drought has been reported as the main driver of beef and sheep production in Australia, New Zealand and Namibia.

Factors driving beef and sheep farming in different countries and regions could be a function of a combination of factors belonging to more than one of the three listed categories. For instance, North African partners referred to drought as a relevant issue besides currency devaluation and inflation. However, to structure the discussion, countries are listed under the category that had the most major impact on beef and sheep meat production and input and output prices at the farm level in 2020.

Lower and/or more volatile producer prices were reported as the main impact of the pandemic at the farm level (Figure 7). Therefore, the following discussion focuses on developments in producer prices in 2020 as a key indicator to highlight how the pandemic and other driving factors interacted to affect the farm level.

The following discussions are clustered under the three main categories outlined above; market developments (including COVID-19 related impacts and other country-specific market aspects), macro-economic conditions and natural conditions. The discussion draws on evidence from official data sources, the agri benchmark database, personal communications with agri benchmark partners, and third-party material.

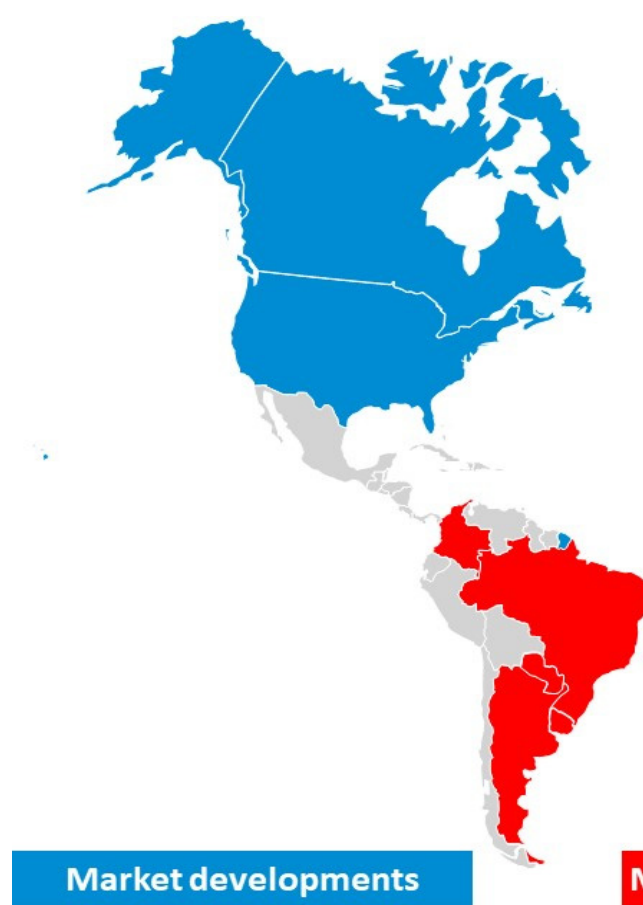

Market developments

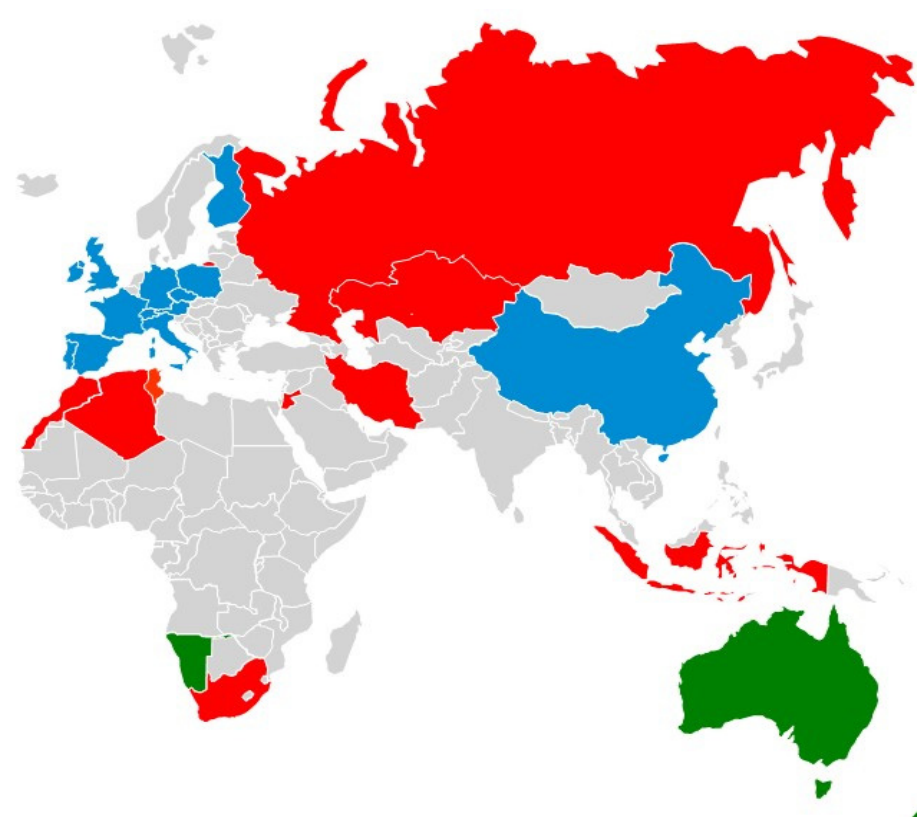

Natural conditions

Figure 8. The main factors impacting beef and sheep prices and farming systems in 2020; Source: Online survey data (n: 32$)$.

\subsubsection{Discussion on Market Developments}

Figure 9 shows the percentage change in local producer prices for beef and sheep meat in the network countries where market-related aspects had the major impact on price developments. 


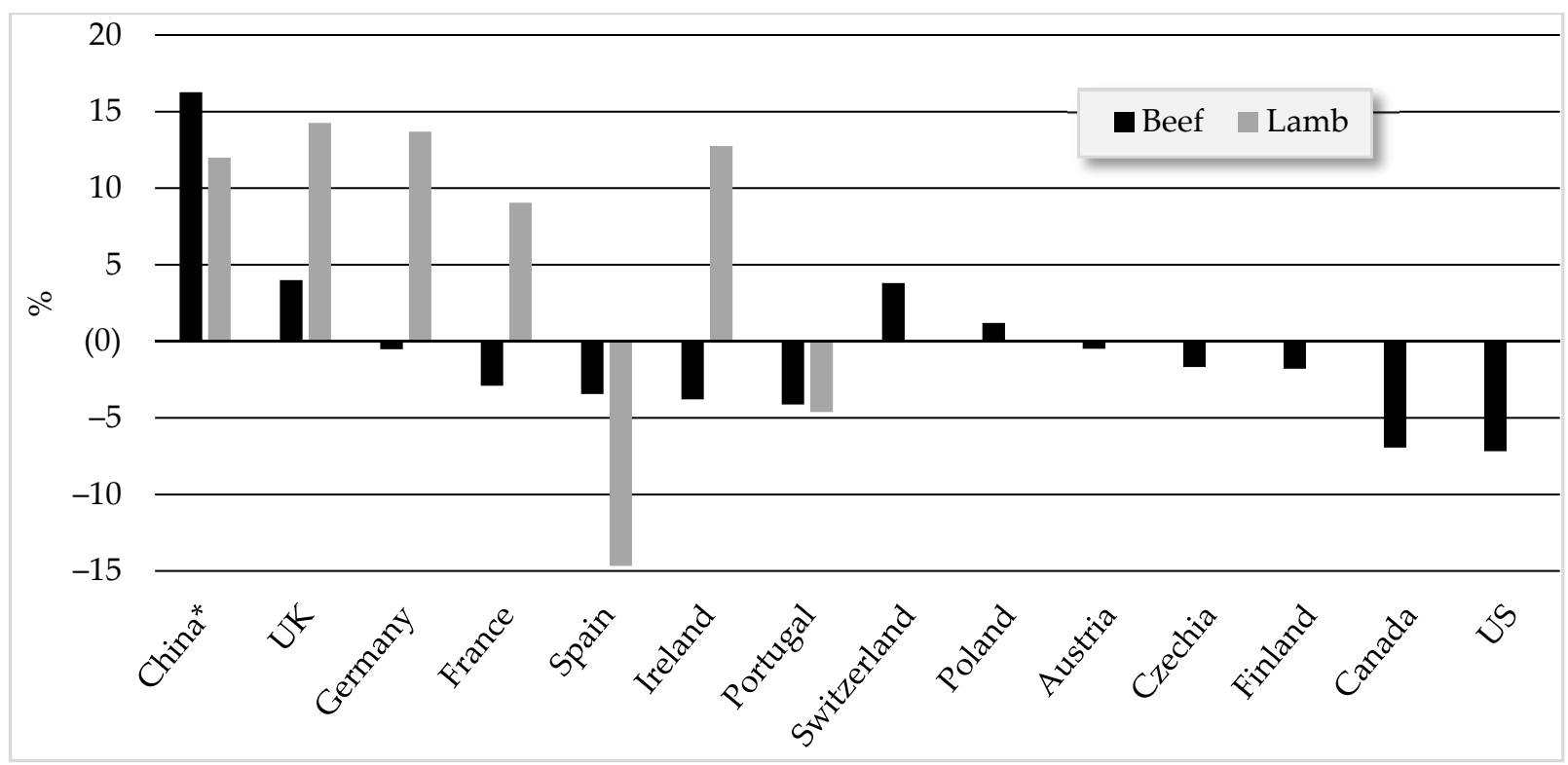

Figure 9. Percentage change of beef and lamb producer prices, 2020 vs. 2019 in national currency, Data ource: agri benchmark beef and sheep network database [42], (* Mutton sheep).

Beef prices in North America were adversely impacted by meat plant disruptions and slowing export flows in 2020, resulting in extreme volatility in U.S. cattle markets. According to the U.S. Department of Agriculture (USDA) [66], the prices of finished steers and heifers were at a high level of USD 125 per hundredweight in January 2020. Contrary to initial forecasts projecting higher U.S. cattle prices during 2020, prices fell to USD 114 in March, when the crisis began impacting the U.S. beef industry (initially though slaughter plant closures). Prices continued to decline to reach the lowest level in July 2020, 28\% below January levels.

Beef production in the U.S had reached a historically high level in 2019, after increasing for four consecutive years, and remained stable in 2020. However, total domestic consumption, which increased slightly, by $0.89 \%$, was not sufficient to absorb such huge supplies of cattle and beef in the U.S. market due to shrinking exports $(-4.9 \%)$ and weak global demand in key export markets (Japan, South Korea and Mexico) [54,67]. Consequently, beef producer prices in the US declined by 7\% in 2020 relative to 2019 (Figure 9).

Beef and sheep producer prices in the EU were also highly impacted by domestic and global market developments in 2020. While domestic consumption has maintained or even exceeded the pre-pandemic levels, the impacts of lockdowns and trade developments varied across the region according to Government responses to the pandemic and sector characteristics in each country.

In the UK, there have been some logistical challenges with beef and sheep exports to European markets related to COVID-19 and Brexit. Despite these challenges, prices reached record levels, particularly for sheep meat-up to $14 \%$-helped by tight domestic supply due to flock rebuilding and producers' concerns around the post-Brexit trade environment $[42,68]$. Intra-EU trade disruptions and the uncertainty around the Brexit trade negotiations in the final quarter of 2020 pushed farmers to sell their animals sooner to avoid the possible impact of no trade deal. However, lamb prices still increased sharply, driven by a $12 \%$ production fall [69]. The agri benchmark database showed a decline in beef and lamb producer prices in Spain by 3\% and 15\%, respectively. The network partners in Spain indicated that "Due to the diminishing per capita consumption of beef and sheep meat in Spain over the last two decades, the cattle and sheep industry is becoming increasingly dependent on the tourism sector and overseas markets. Closure of hotels and restaurants, as a major market channel for Spanish high-priced lamb, resulted in a massive surplus in the market. This, in turn, pushed lamb producer prices down by 15\%" [70]. 
In France and Germany, key importers of sheep meat, the shift from out-of-home (supplied by imports) to home (more domestic production) consumption helped local lamb prices reach unprecedented levels, up by $9 \%$ and $14 \%$ year-on-year in France and Germany, respectively [42].

As shown in Figure 9, China's beef and sheep meat prices rose by $16 \%$ and $12 \%$ in 2020, respectively. This trend is not a function of COVID-19 related issues but rather an ongoing trend over the past two decades, compounded by the impact of African Swine Fever (ASF) since early 2019.

According to the Finished Cattle and Sheep Producer Price Indices introduced by the agri benchmark beef and sheep Network in 2021, beef and sheep meat producer prices in China has had the highest rate of increase over the last two decades (Figure 10) making these prices among the highest in the world. This has been mainly driven by the continuous growth in per capita consumption supported by the rapid development of the Chinese economy, urbanization and middle-class households [33]. Figure 10 also illustrates the continuous increase in per capita consumption of beef and sheep meat in China in the last two decades-expanding by $60 \%$ and $86 \%$, respectively. However, local beef and sheep meat production has failed to keep up with the growing demand, making China the worlds' largest beef and sheep meat importer. The tight supply of Australian sheep meat into China's market in 2020, down by $22 \%$, has also helped prices in China reach record levels.

On top of these factors, the outbreak of ASF in China has provided a temporary shock to China's market for all meats, as pork is the main meat consumed in China. The OECD reported that the ASF outbreak resulted in a $27 \%$ drop in Chinese pig meat production with $15 \%$ reduction in domestic consumption. Falling pig meat supplies have been, in part, compensated for by imports of pork and other meat products [71]. While the volume of China's pig meat imports doubled in 2019 , beef imports grew by $72 \%$ and sheep meat by $42 \%$ [42]. This helps to explain the sharp increase in China's cattle and sheep prices and beef and sheep meat consumption in 2019 and 2020.

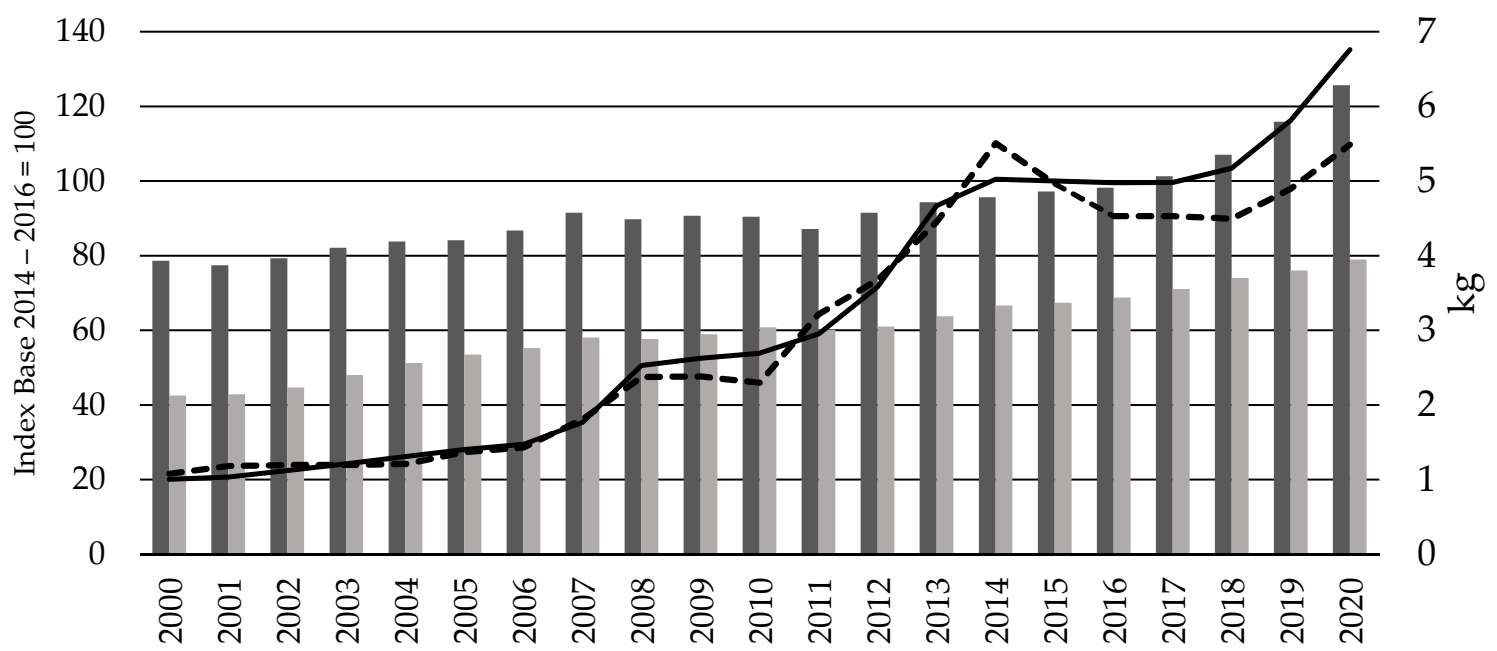

Per capita consumption beef (right axis)

Per capita consumption sheep (right axis)

Finished Cattle Producer Price Index

- - - Sheep Meat Producer Price Index

Figure 10. Beef and sheep meat consumption and producer prices, in national currency, in China. Data source: agri benchmark beef and sheep network database [42].

\subsubsection{Discussion on Macro-Economic Conditions}

Macro-economic conditions were nominated as the main drivers of cattle and sheep prices across a wide range of countries from different continents. To keep it structured, we split this discussion into two sub sections; beef producer countries and sheep producer countries. 


\section{- $\quad$ Beef producer countries}

Figure 11 shows the countries where one or more of the key macro-economic indicators, in particular economic growth, exchange rate developments, inflation rate and/or political instability, had a major impact on beef price developments in 2020. Moreover, it shows the USD price in these countries in order to better reflect the impact of exchange rate developments on the sector.

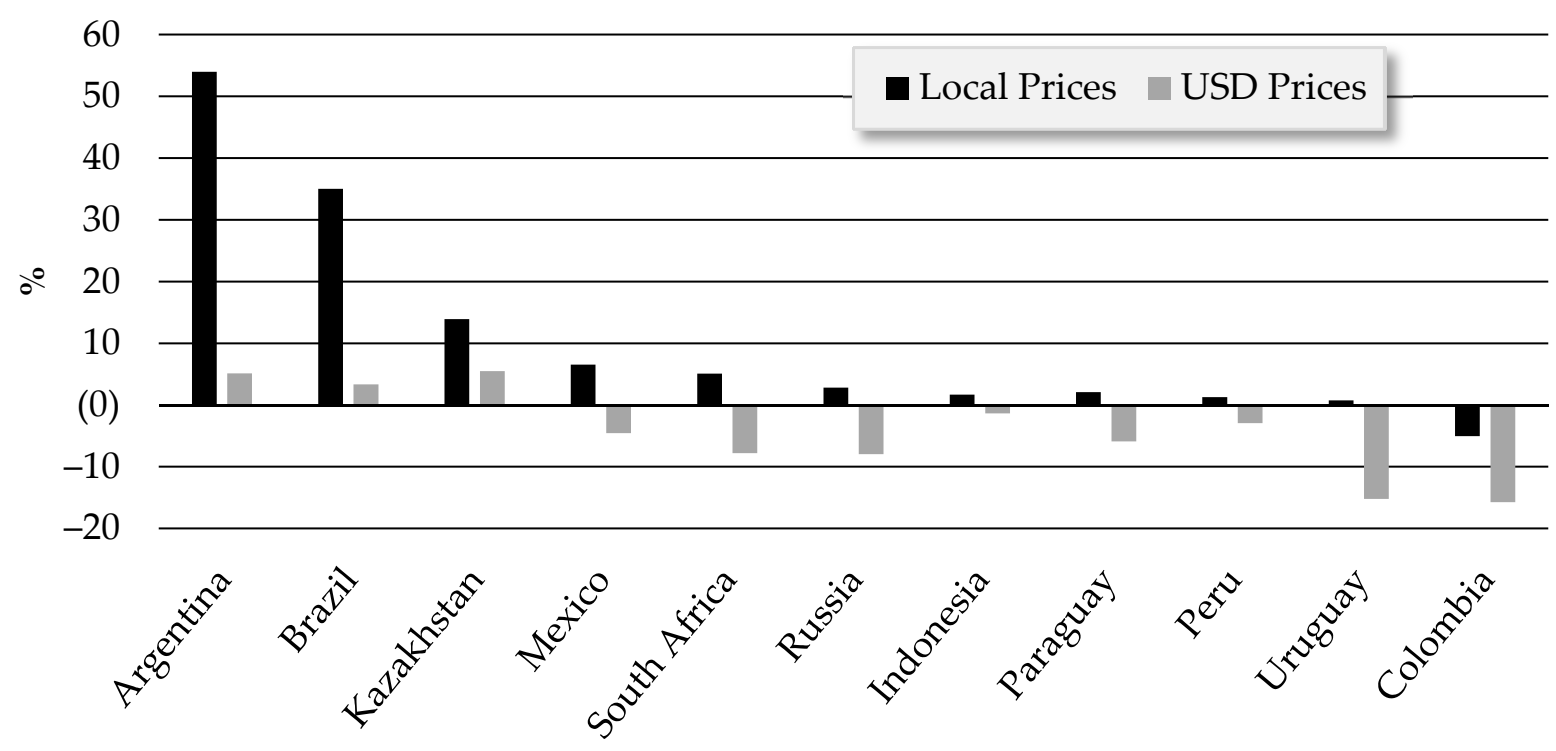

Figure 11. Percentage change of beef producer prices, 2020 vs. 2019 in national currency and USD, Data source: agri benchmark beef and sheep network database [42].

Given Argentina and Brazil's global roles as major beef producers and exporters, it is worthwhile to explain how macro-economic conditions are affecting the production and prices in these countries.

According to Almadani et al. 2021, the rapid deterioration in economic growth and currencies and the political instability across South America were the main drivers of beef production, prices and exports in the region. GDP growth rapidly declined over the past decade leading to little economic growth and recessions in Brazil, Argentina and Uruguay [72,73]. Since 2014, currency devaluation in Argentina and Brazil reached over $700 \%$ and $100 \%$, respectively, while the Uruguay and Colombian pesos are now over 50\% below their peaks in 2011 and 2012, respectively [74].

Figure 12 indicates developments of beef producer prices in South American countries in both local currencies and USD. Such political conditions, inflation and economic downturns have led to a dramatic increase in the domestic beef prices. This, in turn, has severely affected consumer demand for beef [33].

The agri benchmark Beef and Sheep Network Database showed that local beef prices in Brazil have climbed for the third consecutive year, but the 2020 increase was the largest, up $54 \%$ and 35\% relative to 2018 and 2019, respectively. Network partners in Brazil indicated that "The recent increase in beef prices was not only due to the deterioration in economic growth and mounting production costs, but also as a result of production diminishing. The booming international demand (particularly from China) together with low calf prices over the past four years have driven female cattle slaughter up" [75]. Consequently, national beef production in Brazil fell by $4.6 \%$ in 2020 . At the same time, despite the disruptions to global trade flows caused by the COVID-19 crisis, the lower Brazilian currency relative to USD, strong China demand and weak local beef demand helped to boost beef exports by $8 \%$ in 2020 [42]. 


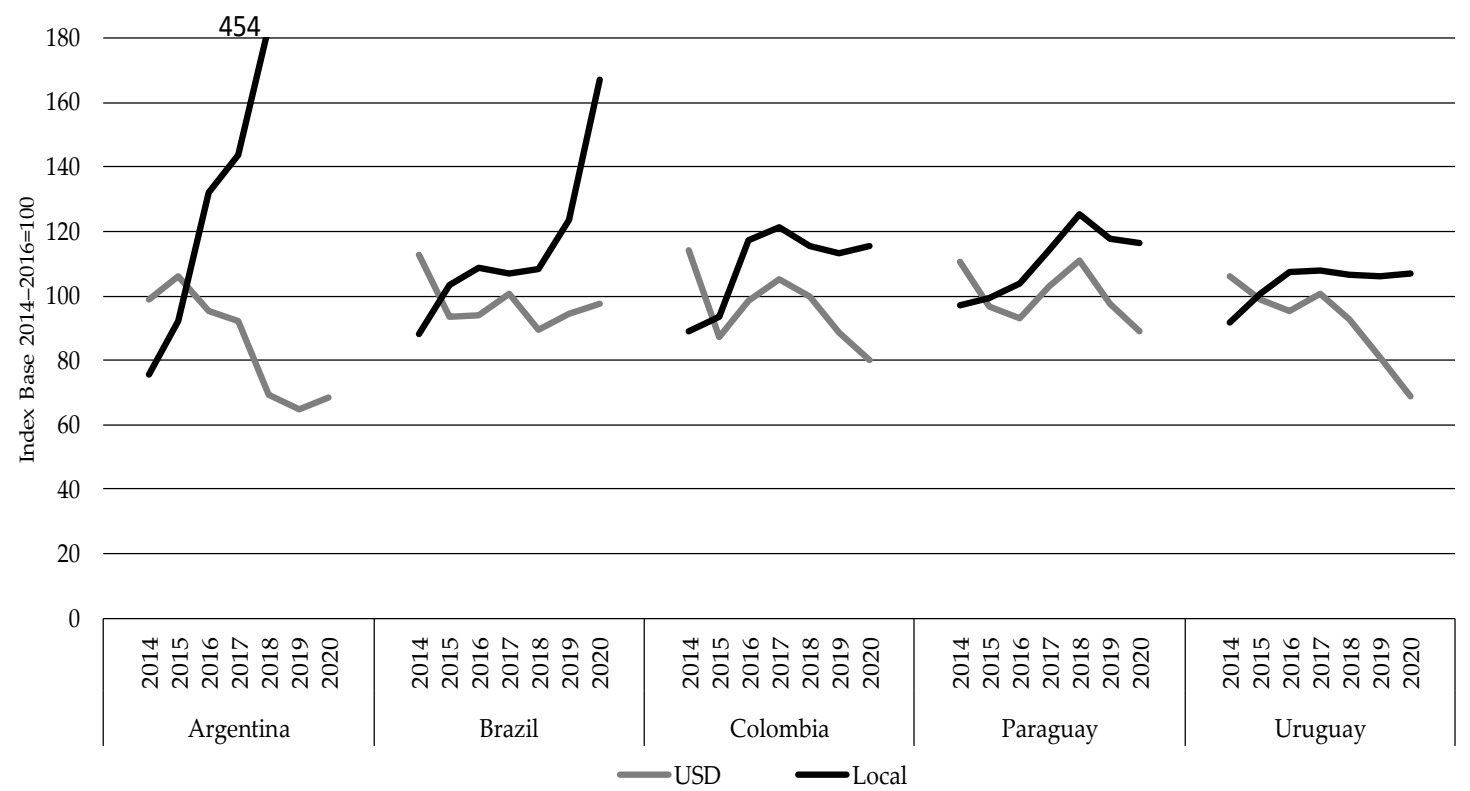

Figure 12. Beef producer price indices in South American countries in national currency and USD, Data source: agri benchmark beef and sheep network database [42].

In addition to the peso's massive devaluation, Argentina's inflation rate is the second highest in South America, after Venezuela, and one of the highest in the world, at $36 \%$ in 2020. Moreover, Argentina faces high levels of poverty (41\%) after almost three years of recession. These factors have been pushing local beef prices lower [76].

Following the elimination of the Argentine Government's beef export bans in 2015, exports have been increasingly attractive relative to the weak domestic market, as economic conditions hit domestic purchasing power. Argentine beef has become extremely attractive on global markets-beef exports totalled 9 million ton in 2020, an increase of $570 \%$ since reopening exports in 2015. China is the main overseas destination for Argentina beef, absorbing $76 \%$ of total beef shipments from Argentina in 2020. In contrast, per capita beef consumption declined by $13 \%$ over the same period.

The rapid rise in local cattle producer prices has not been reflected in beef farm profitability, as the rapid deterioration in the Argentine peso (along with other factors) has also lifted farm input prices. The prices of concentrates, soya bean and corn increased by nearly $40 \%$ year-on-year in 2020 , and by above $400 \%$ since 2016 . Hence, while local cattle prices in Argentina and Brazil increased by $243 \%$ and $54 \%$, respectively, over the last five years, beef farm profits have declined by $80 \%$ and $60 \%$, respectively, over the same period [42].

- $\quad$ Sheep producer countries:

Figure 13 clusters the countries where sheep meat prices have been mainly driven by macro-economic conditions. Algeria and Iran, as the two largest sheep meat producers within these countries [77], will be explained in more details. Furthermore, both countries typically represent challenges that are believed to hamper the development of sheep farming systems throughout the Middle East and North Africa (MENA), mainly economic and political instability.

Moreover, given the arid and semi-arid nature of much of the MENA region, climate change, recurring droughts, desertification and degradation of pasture and rangelands and lack of good quality feed in adequate quantities are all significantly challenging the performance of the sector.

These conditions make the sector highly volatile in terms of production and prices, as the bulk of sheep farming in MENA occurs in the traditional small-scale systems, mainly by subsistence-oriented producers. 
The adverse economic and social consequences of the COVID-19 crisis have compounded the impact of these ongoing economic, political and natural issues in many MENA countries-in common with other low-income countries around the world.

Sheep meat prices in Iran have shown an exponential increase since 2014, up by $400 \%$ and $207 \%$ in local currency and USD, respectively [42]. This is mainly attributed to sanctions against Iran, imposed especially by the United States, resulting in adverse macro-economic conditions, such as massive inflation and currency devaluation. The Iranian rial lost nearly $30 \%$ relative to the USD since 2015 [74]. While the exchange rate remained almost stable in 2020, inflation remained high $-41.2 \%$ in 2019 and $36.4 \%$ in 2020, respectively. Thus, local lamb prices in 2020 jumped by $48 \%$, year-on-year.

Grazing systems account for nearly $60 \%$ of total sheep production in Iran. This makes the sector more vulnerable to widespread droughts which have hit more frequently and severely in the last two decades. Diminished pastures and grain harvests pushed up production costs of sheep farming due to greater reliance on imported feed, which became more expensive. These issues forced some sheep producers out of business, particularly in pasture-based production systems [33]. Consequently, the national sheep flock reached its lowest level ever in 2020, 12\% below 2014 levels [42].

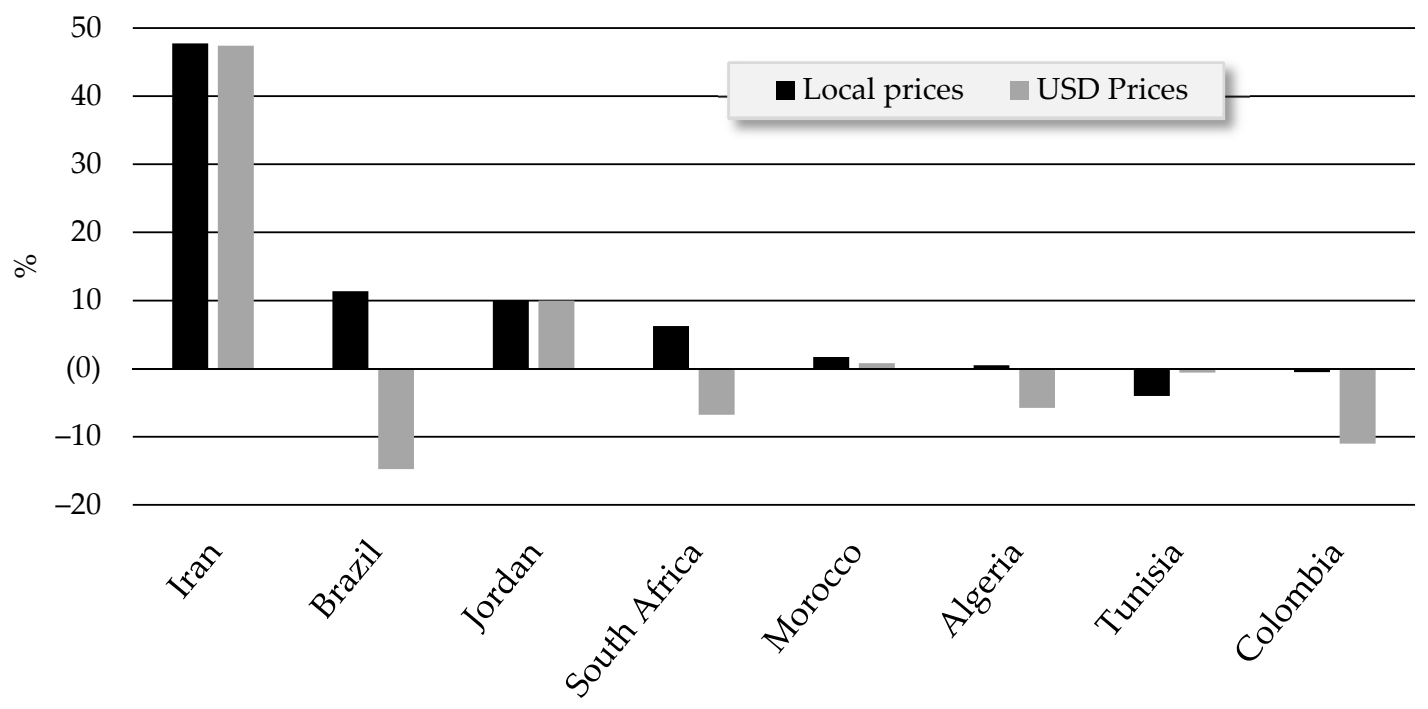

Figure 13. Percentage change of lamb producer prices, 2020 vs. 2019 in national currency and USD, Data source: agri benchmark beef and sheep network database [42].

In Algeria, with oil accounting for more than $90 \%$ of national revenues, economic growth has been hit as global oil prices have plunged since 2014 [78]. Brent Crude prices fell sharply from USD 70/barrel in 2018-2019 to USD 20/barrel in the first quarter 2020, before recovering to US $\$ 40$ for most of 2020 [79]. The Algerian dinar rapidly declined, devaluating by $57 \%$ between 2014 and 2020. The resultant economic downturn has negatively impacted the populations' purchasing power, lowering domestic demand for sheep meat.

The agri benchmark Beef and Sheep Network Database showed that, while local lamb and sheep meat prices remained almost stable between 2014 and 2020, veterinary input prices and feed prices (average barley grain and hay prices) rose by $84 \%$ and $55 \%$, respectively, causing a deterioration in farm profitability.

Although livestock production in Morocco and Jordan is mainly influenced by drought and water scarcity, the fragile economies and political unrest in MENA also cast a shadow on the livestock sector. Economic hardship caused by the pandemic has unavoidably led to a drop in domestic sheep meat consumption in both countries. In Morocco, low domestic demand for sheep meat in 2020 was an obstacle, preventing producer prices from keeping up with increased feed costs following the 2019 drought. Despite falling domestic demand 
in Jordan, sheep meat producer prices in 2020 increased by $10 \%$ compared to 2019, helped by a buoyant export market for live sheep in Gulf Cooperation Council (GCC) countries [80].

\subsubsection{Discussion on Natural Conditions}

Beef and sheep meat production and prices in Australia, New Zealand and Namibia have been principally influenced by natural conditions over recent years, mainly reoccurring severe droughts (Figure 14).

Drought is the key factor impacting the Australian livestock industry, as three severe and prolonged national droughts have occurred over the past 20 years. The severe 2018 2019 drought lowered sheep flock and cattle herd reproductive rates, increased deaths and forced producers to raise cattle and calf turnoff (to slaughter) and production [33]. Cow and heifer slaughter jumped $46 \%$ and the Australian cattle herd declined $12 \%$ over the two years. Similarly, the Australian sheep flock declined 9\% from 70.6 million head in 2018 to an estimated 64 million head in 2020 [42]. A good rainfall season in 2020 encouraged producers to reduce sales of cattle and to buy extra calves for restocking and finishing on ample pasture. Consequently, Australian cattle prices jumped in 2020, with the yearling steer prices up around 30\% and steers bought by restockers up $60 \%$, both to record levels [42]. This was also underpinned by continued strong export and firm domestic demand, despite the impact of COVID-19 on food service demand locally and overseas.

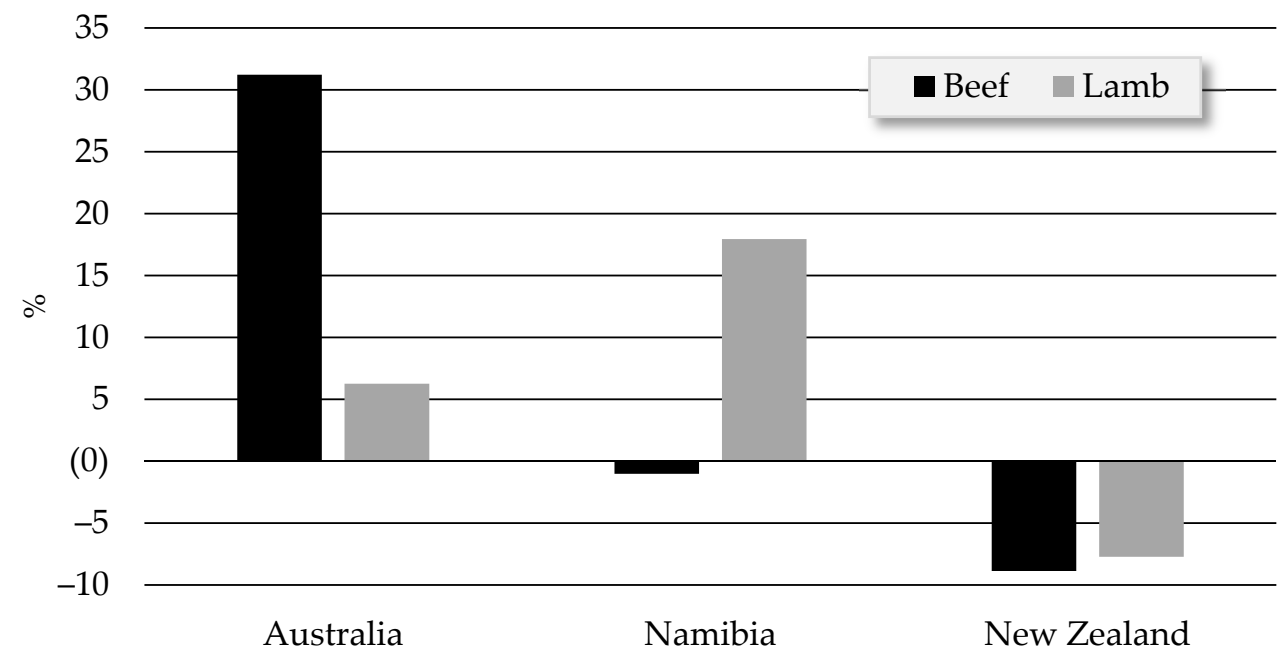

Figure 14. Percentage change of domestic beef and lamb producer prices, 2020 vs. 2019, Data source: agri benchmark beef and sheep network database [42].

The network partners in Australian indicated that "sheep producers were even quicker than cattle producers in cutting back sales of ewes and ewe lambs and in buying in stock for breeding and finishing on ample pasture" [81]. Hence, sheep slaughter fell $30 \%$ and lamb slaughter by $8 \%$ in 2020 and prices rose further by $6 \%$ to post new records. A lower supply, strong restocker demand and rising China demand was sufficient to more than offset the negative demand impact of the pandemic on some sheep meat markets, especially in the Middle East.

The 2020 Beef + Lamb New Zealand report indicated that pasture-based livestock production systems had an extremely challenging year in 2020, with one of the worst, if not the worst, widespread droughts ever recorded. Drought severely hit the entire North Island and upper South Island [82]. This situation has unavoidably led to higher animal slaughter and increased meat supply. The North Island recorded a $4.8 \%$ decline in lamb numbers. As of 30 June 2020, total sheep flock was estimated at 26.2 million, down $2.3 \%$ year on year $[82,83]$. Moreover, steer slaughter lifted, driven by the increasing beef cow herd in the previous two seasons and the subsequent increase in the supply of steers [82]. 
Increased beef and sheep meat supply in New Zealand was met by a weak global food service trade in 2020. The pandemic's impact on the food service sector has strengthened the demand for lower-value meat from New Zealand at the expenses of high-value cuts. Despite stronger domestic meat demand and exports to China, export volumes and revenues fell in 2020, causing a fall in cattle and sheep producer prices [83].

During the rainy season, November 2019 and March 2020, Namibia was recovering from a devastating drought that started in 2013 and reached its height in 2019, as the driest year in almost a century [84]. By the end of 2019, the Namibia sheep flock and cattle herd had dropped by $40 \%$ and $10 \%$ compared to pre-drought in 2013, respectively. The 2004 small stock marketing scheme, a Government policy intervention setting a quota system on the export of live sheep to South Africa, is believed to have hampered the recovery in sheep numbers. The scheme was suspended in 2021 [85]. Under these circumstances, beef prices reached a historic high in 2019, more than double the price in 2013, and sheep meat prices reached the peak in 2020, at 83\% and 18\% higher than 2013 and 2019 levels, respectively [42].

\subsection{Potential Developments in 2021}

During the agri benchmark Conference, participants were asked to select between statements on what had improved the most during the first half of 2021 (Figure 15). The multiple answer poll indicated that $39 \%$ of partners observed a recovery in food service activities in their countries. To anticipate price developments until the end of 2021, partners were also asked to select between suggested price movements scenarios (Figure 15). $77 \%$ of respondents expected an increase in beef and sheep meat prices in 2021, though over half of them indicated that the price increase is likely to be small $(+2 \%$ to $+5 \%)$.

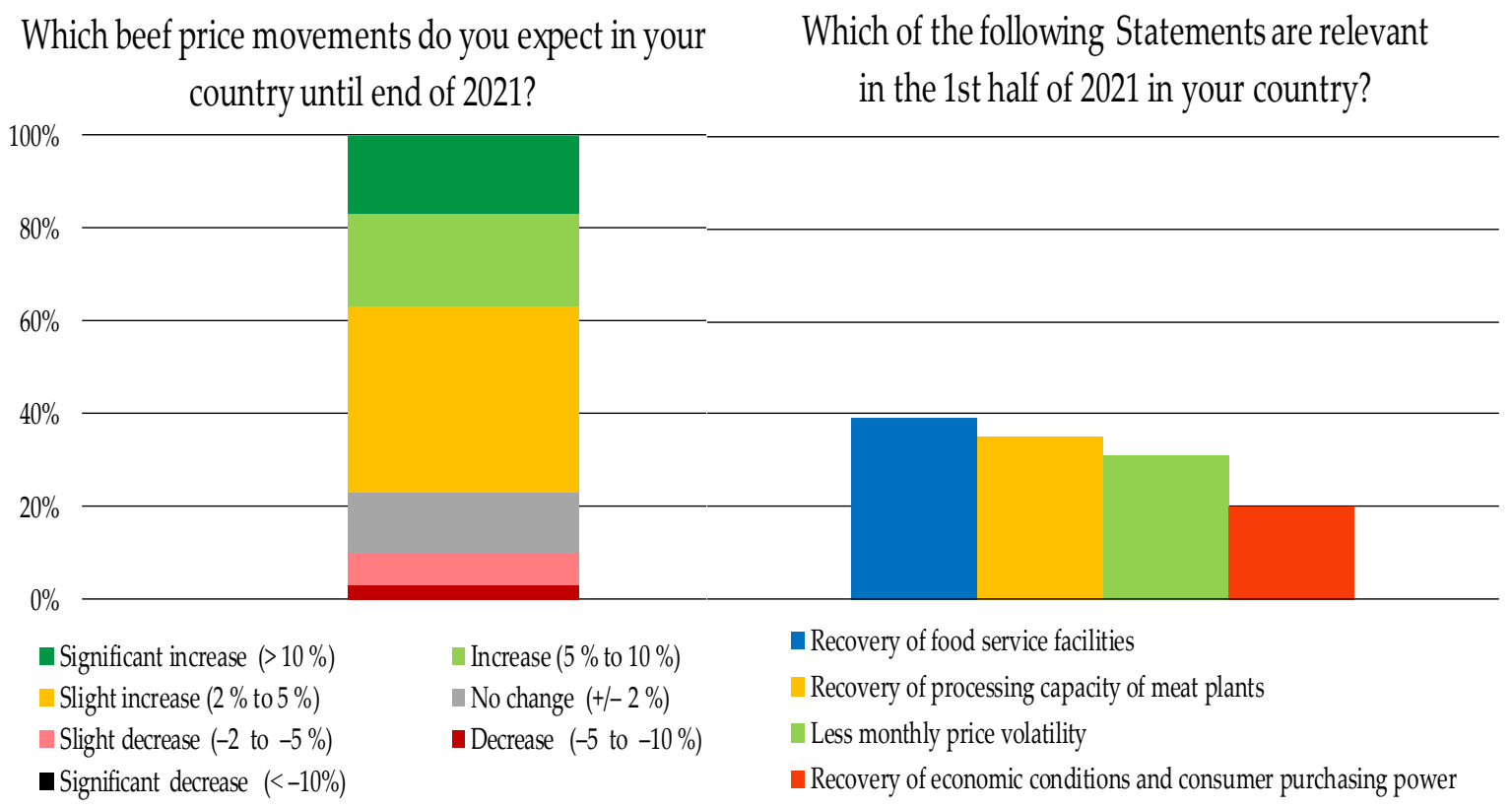

Figure 15. Recovery status of beef and sheep sector in 2021, Data source: Online agri benchmark Conference poll (n: 35).

Looking forward, beef and sheep meat producer prices are expected to rise in 2021, helped by the recovery of food service sales in most western countries, less bottlenecks in meat supply chains, buoyant demand from China and potential lower beef and sheep supply from Argentina and Oceania, respectively.

For example, the restoration of activity in the EU food service facilities in the second quarter of 2021 lifted lamb exports from New Zealand by 10.4\% for the quarter, year-onyear [55]. Also, the beef supply chain in the U.S. seems to have regained its pre-crisis status, which has helped to lift exports to Asian markets, mainly China. 
While U.S. beef exports experienced a decline in 2020 due to the pandemic, they showed a notable rebound in the first half of 2021. Figure 16 reveals that, for the first six months of 2021, U.S. beef export volumes to key Asian markets totalled 361 thousand tons, a 35\% increase compared to the same period in 2020. A sharp increase has been reported for exports to China, reached 76.5 thousand ton, $21 \%$ of total exports to the four key Asian markets compared to only $2 \%$ in 2020 . This indicates the recovery of the U.S supply chain and China shift towards U.S. product for fear of any disruption in Argentinean and Australian beef supply. In May 2021, Argentina imposed a 30-day ban on beef exports to control rising meat prices in the domestic market by temporarily increasing the domestic supply. After that, the government reopen beef exports but with significant restrictions on export volumes (only 50\% of the country's 2020 volume) and with a complete suspension on exporting certain items, such as whole carcass, half carcass and bone-in beef $[86,87]$.

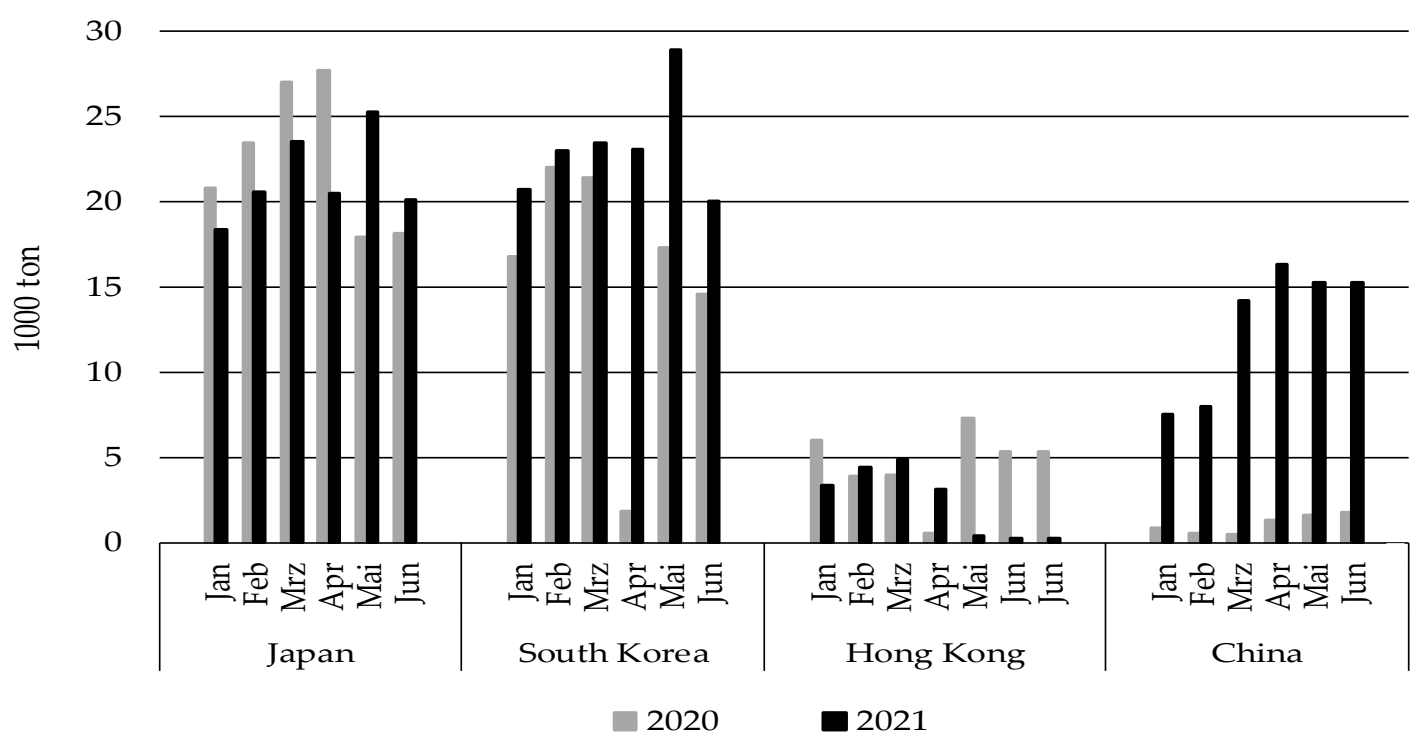

Figure 16. U.S. Beef exports to key markets in Asia, 2021 vs. 2020, Data source: USMEF Export Statistics [54].

Tight lamb supply is expected from Oceania in 2021. Given the lower 2020 lamb crop in New Zealand caused by drought, a 6.5\% decline in lamb exports is forecasted in 2021 [82]. Moreover, lamb supply from Australia to global markets is not expected to increase as producers are most likely to hold onto more ewe lambs to continue rebuilding their flocks over the next few years.

\section{Conclusions}

In conclusion, the results of the study revealed that disruptions caused by the pandemic at meat processing plant and market levels were short lived and limited in influence at farm level-in terms of farm operations, production, and inputs and outputs prices.

Processing disruptions, falling consumer purchasing power in some countries and loss of food service sales have not been found to impact global beef and sheep meat producer prices, which remained buoyant in 2020. To interpret this outcome, the study introduced insights using multiple data sources from a large number of countries.

The study highlighted the promising role of online and e-commerce food delivery platforms, which significantly offset the fall in traditional food service sales in many countries (Section 3.1.2). Furthermore, economic stimulation programs that have been put in place at national and sub-national levels in some, mainly developed, countries have supported per capita consumption of meat (Figure 3).

Factors that have influenced global beef and sheep meat production and prices over the last decade continued to keep producer prices at record levels in 2020, more than offsetting any negative impacts of the pandemic in most countries and regions. Supply disruptions 
resulting from persistent drought waves in Australia and the accelerated growth of meat demand in China are expected to push producer prices to new highs in the near future. In addition, ASF outbreaks are still impacting global pork supplies, elevating demand for other meats, especially beef.

In some countries and regions, particularly South America, the impact of the pandemic has exacerbated existing problems facing beef and sheep producers, principally arising from political instability, low economic growth and consumer purchasing power, high inflation and rapid currency depreciations (Section 3.4.3).

The interactive networking and cooperation between the agri benchmark Beef and Sheep Network partners facilitated an informative and comprehensive (largely qualitative) coverage of the impact of COVID-19 and other developments on beef and sheep sectors worldwide. However, using data from expert assessment has some limitations. One of the main limitations is that partners' answers may reflect their respective areas of expertise. Thus, they may evaluate the impacts of different factors on beef and sheep sectors in an unbalanced way. Factors impacting beef and sheep sectors are highly interlinked and influence each other. Thus, disentangling the impact of this pandemic from other factors was one of the major challenges in this research. For this reason, the study tried to harness multiple data sources in quantitative and qualitative analyses to address the impact of these factors in a more accurate manner (Table 1). Further studies are recommended to investigate the short- and medium-run impact on the beef and sheep sectors of the diverse measures implemented by governmental and industrial institutions to mitigate the spread of the pandemic. Most of these studies would involve case studies and contrasting COVID-19 impacts in selected countries and would be just as relevant to other meats, other food groups or food in general. These include: (i) the impact of fiscal stimulus programs in alleviating the impact of the pandemic on economic growth and consumer spending; (ii) the change in estimated expenditure on beef and/or sheep meat in 2020 in selected countries (or demand using the Purcell Index or other demand indices); and/or (iii) the influence of a country's eating habits and patterns on the impact of the pandemic on the demand for beef (or all meats).

It would also be interesting, though harder, to speculate as to the lasting effects of the pandemic on consumer demand and meat supply chains arising, for example, from altered consumer purchasing habits, working from home and the growth in electronic marketing.

Author Contributions: Conceptualization, M.I.A.; methodology, M.I.A. and P.W.; formal analysis, M.I.A.; writing—original draft preparation, M.I.A. and P.W.; writing—review and editing, M.I.A., P.W. and C.D.; supervision, M.I.A. and P.W. All authors have read and agreed to the published version of the manuscript.

Funding: This research received no external funding.

Institutional Review Board Statement: Not applicable.

Informed Consent Statement: Informed consent was obtained from all subjects involved in the study.

Data Availability Statement: Results of the agri benchmark online survey questionnaire are available upon request. The data obtained from agri benchmark Beef and Sheep Network Database are not publicly available due to scientific cooperation agreements between the agri benchmark Beef and Sheep Network and the Institutional Partners.

Acknowledgments: The authors would like to thank the agri benchmark Beef and Sheep Network partners and their institutions for the fruitful collaboration and for providing and updating relevant national data.

Conflicts of Interest: The authors declare no conflict of interest. 


\section{Appendix A}

\begin{tabular}{|c|c|c|c|c|c|c|c|}
\hline \multicolumn{8}{|c|}{$\begin{array}{l}\text { The questionnaire comprises two sections } \\
\text { COVID-19 issues in } 2020 \text { (Question 2) } \\
\text { Latest developments issues in } 2020 \text { (Question 3) }\end{array}$} \\
\hline 1 & Which country do you present in this questic & Inaire? & & & & & \\
\hline 2 & In what way was COVID-19 pandemic affect & g the follo & ig segments $t$ & oughout 20 & & & \\
\hline \multirow{9}{*}{$2 \mathbf{a}$} & Market & Not at all & Minor & Moderate & Significant & Severe & Don't know \\
\hline & $\begin{array}{l}\text { Economic hardships, reduced household } \\
\text { incomes }\end{array}$ & & & & & & \\
\hline & $\begin{array}{l}\text { Reduced domestic demand and } \\
\text { consumption }\end{array}$ & & & & & & \\
\hline & Drop in food service sales & & & & & & \\
\hline & Drop in out-of-home consumption & & & & & & \\
\hline & $\begin{array}{l}\text { Increased consumers' concerns about meat } \\
\text { origin }\end{array}$ & & & & & & \\
\hline & Slowing trade activities & & & & & & \\
\hline & Large shifts in export/import destinations & & & & & & \\
\hline & Overcrowded cold storage facilities & & & & & & \\
\hline \multirow{4}{*}{$2 b$} & Meat plant & Not at all & Minor & Moderate & Significant & Severe & Don't know \\
\hline & Shortage in meat plants' labour & & & & & & \\
\hline & $\begin{array}{l}\text { COVID-19 outbreaks in slaughterhouses } \\
\text { and meat processing companies }\end{array}$ & & & & & & \\
\hline & Reduced processing capacity of meat plants & & & & & & \\
\hline \multirow{11}{*}{$2 c$} & Farm & Not at all & Minor & Moderate & Significant & Severe & Don't know \\
\hline & Reduced access to farm inputs & & & & & & \\
\hline & $\begin{array}{l}\text { Reduced access to services (e.g. veterinary } \\
\text { extension and drug services) }\end{array}$ & & & & & & \\
\hline & Shortage in farm labour & & & & & & \\
\hline & Reduced feed supply & & & & & & \\
\hline & Increased farm inputs prices & & & & & & \\
\hline & $\begin{array}{l}\text { High monthly volatility of finished animal } \\
\text { prices }\end{array}$ & & & & & & \\
\hline & Reduced producer prices (outpul prices) & & & & & & \\
\hline & $\begin{array}{l}\text { Delayed marketing of finished animals } \\
\text { (overcrowded barns, higher carcass weight) }\end{array}$ & & & & & & \\
\hline & $\begin{array}{l}\text { Reduced pastoralists mobility, accumulation } \\
\text { of free-range animals }\end{array}$ & & & & & & \\
\hline & Reduced national livestock inventories & & & & & & \\
\hline 3 & \multicolumn{7}{|c|}{ Beside the pandemic, how might the following issues have affected beef/sheep sector/s in your country throughout $2020 ?$} \\
\hline \multirow{3}{*}{$3 \mathbf{a}$} & Natural conditions & Relevant & Not relevant & \multicolumn{4}{|c|}{ Further details } \\
\hline & Drought & & & \\
\hline & Flooding & & & & & & \\
\hline \multirow{5}{*}{$2 b$} & Macro-economic conditions & Relevant & Not relevant & \multicolumn{4}{|c|}{ Further details } \\
\hline & Exchange rate developments & & & \\
\hline & Political instability & & & & & & \\
\hline & Inflation & & & & & & \\
\hline & Economic recession & & & & & & \\
\hline \multirow{3}{*}{$2 c$} & Market developments & Relevant & Not relevant & \multicolumn{4}{|c|}{ Further details } \\
\hline & Trade regulations & & & & & & \\
\hline & Demand / supply developments & & & & & & \\
\hline
\end{tabular}

Figure A1. Survey questionnaire. 


\begin{tabular}{|c|c|c|c|c|c|}
\hline Country & Beef & Sheep & Country & Beef & Sheep \\
\hline Algeria & & $\checkmark$ & Mexico & $\checkmark$ & $\checkmark$ \\
\hline Argentina & $\checkmark$ & & Morocco & $\checkmark$ & $\checkmark$ \\
\hline Australia & $\checkmark$ & $\checkmark$ & Namibia & $\checkmark$ & $\checkmark$ \\
\hline Austria & $\checkmark$ & & New Zealand & $\checkmark$ & $\checkmark$ \\
\hline Brazil & $\checkmark$ & $\checkmark$ & Paraguay & $\checkmark$ & \\
\hline Canada & $\checkmark$ & & Peru & $\checkmark$ & \\
\hline China & $\checkmark$ & $\checkmark$ & Poland & $\checkmark$ & \\
\hline Colombia & $\checkmark$ & $\checkmark$ & Portugal & $\checkmark$ & $\checkmark$ \\
\hline Czechia & $\checkmark$ & & Russia & $\checkmark$ & \\
\hline Finland & $\checkmark$ & & South Africa & $\checkmark$ & $\checkmark$ \\
\hline France & $\checkmark$ & $\checkmark$ & Spain & $\checkmark$ & $\checkmark$ \\
\hline Germany & $\checkmark$ & $\checkmark$ & Switzerland & $\checkmark$ & \\
\hline Indonesia & $\checkmark$ & & Tunisia & $\checkmark$ & $\checkmark$ \\
\hline Iran & $\checkmark$ & $\checkmark$ & UK & $\checkmark$ & $\checkmark$ \\
\hline Ireland & $\checkmark$ & $\checkmark$ & Ukraine & $\checkmark$ & $\checkmark$ \\
\hline Italy & $\checkmark$ & & Uruguay & $\checkmark$ & $\checkmark$ \\
\hline Jordan & & $\checkmark$ & US & $\checkmark$ & \\
\hline Kazakhstan & $\checkmark$ & & & & \\
\hline
\end{tabular}

Figure A2. Countries of agri benchmark Beef and Sheep Network.

\begin{tabular}{|l|}
\hline Which of the following statements are relevant in the $\mathbf{1}^{\text {st }}$ half of 2021 in your country? (Multiple choice) \\
\hline 1- Recovery of food service facilities \\
\hline 2- Recovery of processing capacity of meat plants \\
3- Less monthly price volatility \\
\hline 4-Recovery of economic conditions and consumer purchasing power \\
\hline Which beef price movements do you expect in your country until end of 2021? (Single Choice) \\
\hline 1- Significant decrease (<-10\%) \\
\hline 2- Decrease (-5 to $-10 \%)$ \\
\hline 3- Slight decrease $(-2$ to $-5 \%)$ \\
\hline - No change (+/- $\%)$ \\
\hline 5- Slight increase $(2 \%$ to $5 \%)$ \\
\hline 6- Increase (5 \% to $10 \%)$ \\
\hline 7- Significant increase $(>10 \%)$ \\
\hline
\end{tabular}

Figure A3. Poll statements.

\section{References}

1. Hashem, N.M.; González-Bulnes, A.; Rodriguez-Morales, A.J. Animal welfare and livestock supply chain sustainability under the COVID-19 outbreak: An overview. Front. Vet. Sci. 2020, 7, 679. [CrossRef] [PubMed]

2. World Bank. Protecting People and Economies: Integrated Policy Responses to COVID-19; World Bank: Washington, DC, USA, 2020. Available online: https:/ / openknowledge.worldbank.org/handle/10986/33770 (accessed on 18 November 2021).

3. Allain-Dupré, D.; Chatry, I.; Michalun, V.; Moisio, A. The Territorial Impact of COVID-19: Managing the Crisis across Levels of Government; OECD: Paris, France, 2020. Available online: https://www.oecd.org/coronavirus / policy-responses/the-territorialimpact-of-covid-19-managing-the-crisis-across-levels-of-government-d3e314e1/ (accessed on 19 November 2021).

4. Diaz, E.A.; Scudiero, L.; Schneider, F.; Steinfeld, H. GASL Stakeholder Consultation on COVID10 in the Livestock Sector in April-May; Food and Agriculture Organization of the United Nations (FAO): Rome, Italy, 2020; Global Agenda for Sustainable Livestock (GASL). Available online: http://www.livestockdialogue.org/fileadmin/templates/res_livestock/docs/2020_GASL_Global_ Consultation_report_COVID-19_Impacts.pdf (accessed on 19 January 2021).

5. Organization for Economic Co-operation and Development (OECD). COVID-19 and the Food and Agriculture Sector: Issues and Policy Responses; Policy Brief: Paris, France, 2020. Available online: https:/ /www.oecd.org/coronavirus/policy-responses /covid19-and-the-food-and-agriculture-sector-issues-and-policy-responses-a23f764b / (accessed on 5 May 2021).

6. Jámbor, A.; Czine, P.; Balogh, P. The impact of the coronavirus on agriculture: First evidence based on global newspaper. Sustainability 2020, 12, 4535. [CrossRef] 
7. Seleiman, M.F.; Selim, S.; Alhammad, B.A.; Alharbi, B.M.; Juliatti, F.C. Will novel coronavirus (Covid-19) pandemic impact agriculture, food security and animal sectors? Biosci. J. 2020, 36, 4. [CrossRef]

8. Aday, S.; Aday, M.S. Impact of COVID-19 on the food supply chain. Food Qual. Saf. 2020, 4, 167-180. [CrossRef]

9. Mardones, F.O.; Rich, K.M.; Boden, L.A.; Moreno-Switt, A.I.; Caipo, M.L.; Zimin-Veselkoff, N.; Alateeqi, A.M.; Baltenweck, I. The COVID-19 pandemic and global food security. Front. Vet. Sci. 2020, 7, 928. [CrossRef]

10. Beckman, J.; Baquedano, F.; Countryman, A. The impacts of COVID-19 on GDP, food prices, and food security. Q Open 2021, 1 , qoab005. [CrossRef]

11. FAO. Impact of COVID-19 on Agriculture, Food Systems and Rural Livelihoods in Eastern Africa: Policy and Programmatic Options; FAO Subregional Office for Eastern Africa (SFE): Addis Ababa, Ethiopia, 2020. [CrossRef]

12. Éliás, B.A.; Jámbor, A. Food Security and COVID-19: A Systematic Review of the First-Year Experience. Sustainability 2021, 13, 5294. [CrossRef]

13. Gilmour, B.; Lin, T.; Lee, S. COVID-19 Pandemic Implications on Agriculture and Food Consumption, Production and Trade in ASEAN Member States; Asia Pacific Foundation of Canada: Vancouver, BC, Canada, 2021. Available online: https: / / www.asiapacific.ca/sites/default/files/publication-pdf/COVID-19\%20Pandemic\%20Implications\%20on\%20Agriculture\% 20and\%20Food\%20Consumption\%2C\%20Prod....pdf (accessed on 14 July 2021).

14. Weersink, A.; von Massow, M.; Bannon, N.; Ifft, J.; Maples, J.; McEwan, K.; McKendree, M.G.S.; Nicholson, C.; Novakovic, A.; Rangarajan, A.; et al. COVID-19 and the agri-food system in the United States and Canada. Agric. Syst. 2021, 188, 103039. [CrossRef]

15. Oyeagu, C.E.; Ezeuko, A.S.; Lewu, F.B.; Akuru, E.A.; Ogwuegbu, M.C.; Osita, C.O.; Ani, A.O.; Mlambo, V. The impact of Covid-19 on the livestock industry and the way forward. Adv. Anim. Vet. Sci. 2021, 9, 941-955. [CrossRef]

16. Ijaz, M.; Yar, M.K.; Badar, I.H.; Ali, S.; Islam, M.; Jaspal, M.H.; Hayat, Z.; Sardar, A.; Ullah, S.; Guevara-Ruiz, D. Meat production and supply chain under COVID-19 scenario: Current trends and future prospects. Front. Vet. Sci. 2021, 8, 432. [CrossRef]

17. Abu Hatab, A.; Krautscheid, L.; Boqvist, S. COVID-19, Livestock Systems and Food Security in Developing Countries: A Systematic Review of an Emerging Literature. Pathogens 2021, 10, 586. [CrossRef] [PubMed]

18. Mercy Corps. COVID-19 and Livestock Market Systems: The Impact of COVID-19 on Livestock-Based Economies in the Horn of Africa; Mercy Corps: Portland, OR, USA, 2020. Available online: https://www.mercycorps.org/sites/default/files/2020-08/MC-HoACOVID-Impact-Livestock-Mrkts-Aug-2020.pdf (accessed on 2 April 2021).

19. Aariözkan, S.; Akçay, A.; Küçükoflaz, M.; Güngör, G. The short-term impact of the Covid-19 pandemic on livestock products and feed prices in Turkey. Ank. Üniversitesi Vet. Fakültesi Derg 2021, 68, 337-342. [CrossRef]

20. Marchant-Forde, J.N.; Boyle, L.A. COVID-19 effects on livestock production: A One Welfare issue. Front. Vet. Sci. 2020, 7, 734. [CrossRef]

21. Sartin, J.L. COVID-19 and How it Affects the World of Livestock. Anim. Front. 2021, 11, 71. [CrossRef]

22. Patrice, T.; Lamboni, D. COVID-19 and the Beef Supply Chain: An Overview; Statistics Canada: Ottawa, ON, Canada, 2020. Available online: https:/ / www150.statcan.gc.ca/n1/en/catalogue/45280001 (accessed on 5 July 2021).

23. Rude, J. COVID-19 and the Canadian cattle/beef sector: Some preliminary analysis. Can. J. Agric. Econ. 2020, 68, 207-213. [CrossRef]

24. Fleming, O.M. Modeling the US Beef Industry's Response to COVID-19. Undergrad. Econ. Rev. 2020, 17, 14. Available online: https:/ / digitalcommons.iwu.edu/uer/vol17/iss1/14 (accessed on 5 July 2021).

25. Peel, D.S.; Aherin, D.; Blach, R.; Burdine, K.; Close, D.; Hagerman, A.; Maples, J.; Robb, J.; Tonsor, G. Economic Damages to the US Beef Cattle Industry Due to COVID-19; Oklahoma Cooperative Extension Service: Oklahoma City, OK, USA, 2020. Available online: https: / / extension.okstate.edu/fact-sheets/economic-damages-to-the-u-s-beef-cattle-industry-due-to-covid-19.html (accessed on 5 July 2021).

26. Vidaurreta, I.; de la Fe, C.; Orengo, J.; Gómez-Martín, Á.; Benito, B. Short-term economic impact of COVID-19 on Spanish small ruminant flocks. Animals 2020, 10, 1357. [CrossRef]

27. Meuwissen, M.P.M.; Feindt, P.H.; Slijper, T.; Spiegel, A.; Finger, R.; de Mey, Y.; Paas, W.; Termeer, K.J.A.M.; Poortvliet, P.M.; Peneva, M.; et al. Impact of Covid-19 on farming systems in Europe through the lens of resilience thinking. Agric. Syst. 2021, 191, 103-152. [CrossRef]

28. Balagtas, J.; Cooper, J. The Impact of COVID-19 on United States Meat and Livestock Markets; U.S. Department of Agriculture, Office of the Chief Economist: Washington, DC, USA, 2021. Available online: https://www.usda.gov/sites/default/files/documents/ covid-impact-livestock-markets.pdf (accessed on 5 July 2021).

29. Martinez, C.C.; Maples, J.G.; Benavidez, J. Beef cattle markets and COVID-19. Appl. Econ. Perspect. Policy 2021, 43, 304-314. [CrossRef]

30. Mallory, M.L. Impact of COVID-19 on medium-term export prospects for soybeans, corn, beef, pork, and poultry. Appl. Econ. Perspect. Policy 2021, 43, 292-303. [CrossRef]

31. Ramsey, A.F.; Goodwin, B.K.; Hahn, W.F.; Holt, M.T. Impacts of COVID-19 and price transmission in US meat markets. Agric. Econ. 2021, 52, 441-458. [CrossRef] [PubMed]

32. OECD/FAO. OECD-FAO Agricultural Outlook 2020-2029; FAO: Rome, Italy; OECD Publishing: Paris, France, 2020. [CrossRef]

33. Almadani, M.I.; Weeks, P.; Deblitz, C. Introducing the World's First Global Producer Price Indices for Beef Cattle and Sheep. Animals 2021, 11, 2314. [CrossRef] [PubMed] 
34. Peel, D. Beef supply chains and the impact of the COVID-19 pandemic in the United States. Anim. Front. 2021, 11, 33-38. [CrossRef] [PubMed]

35. FAO. Guidelines to Mitigate the Impact of the COVID-19 Pandemic on Livestock Production and Animal Health; FAO: Rome, Italy, 2020. Available online: http://www.fao.org/in-action/kore/publications/publications-details/en/c/1277631/ (accessed on 12 November 2020).

36. Chibanda, C.; Agethen, K.; Deblitz, C.; Zimmer, Y.; Almadani, M.I.; Garming, H.; Rohlmann, C.; Schütte, J.; Thobe, P.; Verhaagh, M.; et al. The typical farm approach and its application by the Agri Benchmark network. Agriculture 2020, 10, 646. [CrossRef]

37. Agethen, K.; Weeks, P. Climate Change Adaptation Strategies in Beef and Sheep Production; Thünen Institute of Farm Economics: Braunschweig, Germany, 2020. Available online: http:/ / www.agribenchmark.org/agri-benchmark/news-and-results/einzelansicht/ artikel// climate-chan-1.html (accessed on 12 November 2020).

38. Hobbs, J.E. Food supply chains during the COVID-19 pandemic. Can. J. Agric. Econ. 2020, 68, 171-176. [CrossRef]

39. Malhotra, S.; Chhibber-Goel, J.; Krishnan, N.M.A.; Sharma, A. The profiles of first and second SARS-CoV-2 waves in the top ten COVID-19 affected countries. J. Glob. Health Rep. 2021, 5, e2021082. [CrossRef]

40. Tonsor, G.T.; Lusk, J.L.; Tonsor, S.L. Meat Demand Monitor during COVID-19. Animals 2021, 11, 1040. [CrossRef] [PubMed]

41. USDA. Meat Supply and Disappearance; U.S. Department of Agriculture, Economic Research Service, Livestock \& Meat Domestic Data: Washington, DC, USA, 2021. Available online: https://www.ers.usda.gov/webdocs/DataFiles/51875/MeatSDFull.xlsx? $\mathrm{v}=8992.5$ (accessed on 12 August 2021).

42. Agri Benchmark Beef and Sheep Network, Database; Thünen Institute of Farm Economics: Braunschweig, Germany, 2020. Available online: http:/ / www.agribenchmark.org/beef-and-sheep.html (accessed on 12 July 2021).

43. Gladman, R. Retail Gains Offset Cautious Return to out-of-Home Dining; Agriculture and Horticulture Development Board AHDB: Kenilworth, Warwickshire, UK, 2020. Available online: https:/ /ahdb.org.uk/news/consumer-insight-retail-gains-offset-cautiousreturn-to-out-of-home-dining (accessed on 11 July 2021).

44. MLA. Market Snapshot: Beef and Sheepmeat_-Greater China; Meat \& Livestock Australia MLA: North Sydney, NSW, Australia, 2020 Available online: https:/ / www.mla.com.au/globalassets/mla-corporate/prices--markets/documents/os-markets/red-meatmarket-snapshots/2020/greater-china_2020-mla-mi-snapshot-28092020-distribution.pdf (accessed on 17 May 2021).

45. FAO. Mitigating the Impacts of COVID-19 on the Livestock Sector; FAO: Rome, Italy, 2020; ISBN 978-92-5-132512-4. Available online: http:/ / www.fao.org/documents/card/en/c/ca8799en/ (accessed on 20 June 2021).

46. IMF. Database of Fiscal Policy Responses to COVID-19; IMF Fiscal Affairs Department, International Monetary Fund: Washington DC, USA, 2021. Available online: https://www.imf.org/en/Topics/imf-and-covid19/Fiscal-Policies-Database-in-Response-toCOVID-19 (accessed on 19 September 2021).

47. Arelovich, H.M. Facts and thoughts on how the COVID-19 pandemic has affected animal agriculture in Argentina. Anim. Front. 2021, 11, 28-32. [CrossRef]

48. MAGYP. Principales Indicadores del Sector Bovino; Ministerio de Agricultura, Ganadería y Pesca-Argentina MAGYP: Buenos Aires, Argentina, 2021. Available online: https://www.magyp.gob.ar/sitio/areas/bovinos/informacion_sectorial/_archivos/000030 _Indicadores/000001-\%20Indicadores\%20bovinos\%20mensuales.pdf (accessed on 20 August 2021).

49. MAGYP. Evolución mensual y anual de los indicadores: Porcinos; Ministerio de Agricultura, Ganadería y Pesca-Argentina MAGYP: Buenos Aires, Argentina, 2021. Available online: https://www.magyp.gob.ar/sitio/areas/porcinos/estadistica/_archivos//000 007_Evoluci\%C3\%B3n\%20de\%20los\%20Indicadores/000000_Evoluci\%C3\%B3n\%20mensual\%20y\%20anual\%20de \%20los \%20 indicadores.pdf (accessed on 20 August 2021).

50. CEPEA. Valuations of Fed Cattle and Beef in 2021 Are Practically the Same; Center for Advanced Studies on Applied Economics CEPEA: São Paulo, Brazil, 2021. Available online: https://www.cepea.esalq.usp.br/en/brazilian-agribusiness-news/valuationsof-fed-cattle-and-beef-in-2021-are-practically-the-same.aspx (accessed on 20 August 2021).

51. ABPA. Consumo Per Capita de Carne de Frango no Brasil ( $\mathrm{Kg} / \mathrm{Hab})$; Estatística do Setor, Aves, Associação Brasileira de Proteína Animal ABPA: São Paulo, Brazil, 2021. Available online: https:/ / abpa-br.org/mercados/ (accessed on 20 August 2021).

52. USMEF. November Beef Exports Largest in More than a Year; 2020 Pork Exports Top Previous Annual Record; U.S. Meat Export Federation USMEF: Denver, CO, USA, 2021. Available online: https:/ / www.usmef.org/news-statistics/press-releases/november-beefexports-largest-in-more-than-a-year-2020-pork-exports-top-previous-annual-record/ (accessed on 11 July 2021).

53. MDIC. Brazilian Foreign Trade Statistics; Ministério da Indústria, Comércio Exterior e Serviços MDIC: Brasília, Brazil, 2021 Available online: http:/ / comexstat.mdic.gov.br/en/home (accessed on 15 June 2021).

54. USMEF. Export Statistics; U.S. Meat Export Federation USMEF: Denver, CO, USA, 2021. Available online: https://www.usmef. org/news-statistics/statistics/?stat_year=2020 (accessed on 11 July 2021).

55. B+LNZ. Meat Export Tool; Beef + Lamb New Zealand: Wellington, New Zealand, 2021. Available online: https://beeflambnz com/data-tools/meat-export-tool (accessed on 19 August 2021).

56. Mano, A. Special Report: How COVID-19 Swept the Brazilian Slaughterhouses of JBS, World's Top Meatpacker; Thomson Reuters: London, UK, 2020. Available online: https:/ /www.reuters.com/article/uk-health-coronavirus-jbs-specialreport-idUKKBN25Z1 I4 (accessed on 11 July 2021).

57. Lusk, J.L.; Tonsor, G.T.; Schulz, L.L. Beef and pork marketing margins and price spreads during COVID-19. Appl. Econ. Perspect. Policy 2021, 43, 4-23. [CrossRef] 
58. Waltenburg, M.A.; Victoroff, T.; Rose, C.E.; Butterfield, M.; Jervis, R.H.; Fedak, K.M.; Gabel, J.A.; Feldpausch, A.; Dunne, E.M.; Austin, C.; et al. Update: COVID-19 Among Workers in Meat and Poultry Processing Facilities-United States, April-May 2020; US Department of Health and Human Services/Centers for Disease Control and Prevention: Washington, DC, USA, 2020; pp. 887-892. [CrossRef]

59. Hobbs, J.E. The Covid-19 pandemic and meat supply chains. Meat Sci. 2021, 181, 108459. [CrossRef]

60. Dyal, J.W.; Grant, M.P.; Broadwater, K.; Bjork, A.; Waltenburg, M.A.; Gibbins, J.D.; Hale, C.; Silver, M.; Fischer, M.; Steinberg, J.; et al. COVID-19 Among Workers in Meat and Poultry Processing Facilities-19 States, April 2020; US Department of Health and Human Services/Centers for Disease Control and Prevention: Washington, DC, USA, 2020; pp. 557-561. [CrossRef]

61. World Farmers' Organization (WFO). COVID-19 Pandemic Outbreak: Overview of the Impact on the Agricultural Sector. A Technical Assessment of the Undergoing Situation; WFO: Rome, Italy, 2020. Available online: https://www.wfo-oma.org/wp-content/ uploads/2020/05/COVID19-WFO-technical-assessment_005082020.pdf (accessed on 30 September 2020).

62. Lee, G. Coronavirus: What went wrong at Germany's Gütersloh meat factory? BBC News: London, UK, 2020. Available online: https:/ / www.bbc.com/news/world-europe-53177628 (accessed on 1 July 2020).

63. BBC News. Coronavirus: German Outbreak Sparks Fresh Local Lockdowns; BBC News: London, UK, 2020. Available online: https:/ / www.bbc.com/news/world-europe-53149762 (accessed on 1 July 2020).

64. Business and Human Rights Resource Centre. Germany: Cabinet Proposes New Regulations to Better Protect Meatpacking Workers Following COVID-19 Outbreaks at Slaughterhouses; Business and Human Rights Resource Centre: London, UK, 2020. Available online: https: / / www.business-humanrights.org/en/latest-news/germany-cabinet-proposes-new-regulations-to-better-protectmeatpacking-workers-following-covid-19-outbreaks-at-slaughterhouses/ (accessed on 5 July 2021).

65. Deutsche Welle. German Government Approves Stricter Rules for Meat Industry; Deutsche Welle (DW): Bonn, Germany, 2020. Available online: https://www.dw.com/en/german-government-approves-stricter-rules-for-meat-industry/a-55750116 (accessed on 28 January 2021)

66. USDA. Prices Received: Cattle Prices Received by Month, US; U.S. Department of Agriculture, National Agricultural Statistics Service: Washington, DC, USA, 2021. Available online: https:/ /www.nass.usda.gov/Charts_and_Maps/Agricultural_Prices/priceca.php (accessed on 6 August 2021).

67. USDA/FAS. Market and Trade Data; U.S. Department of Agriculture, Foreign Agricultural Service FAS: Washington, DC, USA 2021. Available online: https://apps.fas.usda.gov/psdonline/app/index.html\#/app/advQuery (accessed on 6 August 2021).

68. Wright, R. Lamb Market Outlook; Agriculture and Horticulture Development Board AHDB: Kenilworth, UK, 2021. Available online: https:/ / ahdb.org.uk/lamb-market-outlook (accessed on 30 August 2021).

69. Murray, M. Brexit 'No Deal' Scenario Poses Serious Threat to Irish Farmers; Special Report, The Irish Times: Dublin, Ireland, 2020. Available online: https:/ / www.irishtimes.com/special-reports/the-future-of-farming/brexit-no-deal-scenario-poses-seriousthreat-to-irish-farmers-1.4346742 (accessed on 30 August 2021).

70. Tragsa Group, Madrid, Spain. Personal communication, 2021.

71. Frezal, C.; Gay, S.; Nenert, C. The Impact of the African Swine Fever Outbreak in China on Global Agricultural Markets; OECD: Paris, France, 2021. [CrossRef]

72. Spilimbergo, M.A.; Srinivasan, M.K. Brazil: Boom, Bust, and the Road to Recovery; International Monetary Fund: Washington, DC, USA, 2019; ISBN 9781484339749. [CrossRef]

73. Dwyer, B. Latin America: An End to Boom and Bust? Euromoney Institutional Investor PLC: London, UK, 2019. Available online: https:/ / www.euromoney.com/article/b1dd4cf9mv160j/latin-america-an-end-to-boom-and-bust (accessed on 13 January 2021).

74. OANDA Corporation. Historical Exchange Rates; OANDA Corporation: New York, NY, USA, 2020. Available online: https: //www.oanda.com/fx-for-business/historical-rates (accessed on 15 May 2020).

75. CEPEA. Center for Advanced Studies on Applied Economics; CEPEA: São Paulo, Brazil, 2021; Personal communication.

76. Deutsche Welle. Argentina Cerró 2020 con una Inflación de 36\%; Deutsche Welle (DW): Bonn, Germany, 2021. Available online: https:/ / www.dw.com/es/argentina-cerr\%C3\%B3-2020-con-una-inflaci\%C3\%B3n-de-36/a-56229478 (accessed on 15 May 2020).

77. FAO. FAOSTAT Statistical Database; FAO: Rome, Italy, 2020.

78. Allouche, Y. Algerians Are Hurting: Dinar's Dramatic Fall Deepens Economic Woes; Middle East Eye MEE: London, UK, 2020. Available online: https:/ / www.middleeasteye.net/news/algeria-dinar-record-low-economic-collapse (accessed on 17 August 2021).

79. Trading Economics. Brent Crude Oil; Trading Economics: New York, NY, USA, 2021. Available online: https://tradingeconomics. com/commodity/brent-crude-oil (accessed on 9 September 2021).

80. USDA. Grain and Feed Annual_Jordan; U.S. Department of Agriculture, Foreign Agricultural Service: Washington, DC, USA, 2021. Available online: https:/ /apps.fas.usda.gov/newgainapi/api/Report/DownloadReportByFileName?fileName=Grain\% 20and\%20Feed\%20Annual_Amman_Jordan_03-15-2021 (accessed on 9 September 2021).

81. Weeks Consulting Services Pty Ltd., Sydney, NSW, Australia. Personal communication, 2021.

82. B+LNZ. New Season Outlook 2020-2021; Beef + Lamb New Zealand: Wellington, New Zealand, 2020. Available online: https:/ / beeflambnz.com/sites/default/ files/data/files/B\%2BLNZ\%20New\%20Season\%20Outlook\%202020-21.pdf (accessed on 9 September 2021).

83. B+LNZ. Mid-Season Update 2020-2021; Beef + Lamb New Zealand: Wellington, New Zealand, 2021. Available online: https: / /beeflambnz.com/sites/default/files/data/files/MidSeason\%20Update\%20\%28MSU\%29\%202020-21\%20Report.pdf (accessed on 9 September 2021). 
84. Nyaungwa, N. Severe Drought to Hit Namibia's Meat Industry after Cattle Herds Decimated. Thomson Reuters: London, UK, 2020. Available online: https://www.reuters.com/article/ozatp-uk-namibia-meat-idAFKBN28M09M-OZATP (accessed on 25 August 2021).

85. Ackermann, B. Namibia: Sheep Production Figures Drop Due to Drought; ProAgri: Pretoria, South Africa, 2021. Available online: https:/ / www.proagri.co.za/en/namibia-sheep-production-figures-drop-due-to-drought/ (accessed on 25 August 2021).

86. USDA. Argentina: 30-Day Beef Export Ban; U.S. Department of Agriculture, Foreign Agricultural Service: Washington, DC, USA, 2021. Available online: https://www.fas.usda.gov/data/argentina-argentina-imposes-30-day-beef-export-ban (accessed on 12 September 2021).

87. FAO. Meat Market Review: Price and Policy Update; FAO: Rome, Italy, 2021. Available online: https://www.fao.org/3/cb6127en/ cb6127en.pdf (accessed on 10 September 2021). 